\title{
Satellite observations of aerosol transport from East Asia to the Arctic: three case studies
}

\author{
M. Di Pierro, L. Jaeglé, and T. L. Anderson \\ Department of Atmospheric Sciences, University of Washington, Seattle, Washington, USA \\ Received: 24 September 2010 - Published in Atmos. Chem. Phys. Discuss.: 1 November 2010 \\ Revised: 1 March 2011 - Accepted: 1 March 2011 - Published: 11 March 2011
}

\begin{abstract}
Vertical profiles of aerosol extinction obtained with the CALIOP lidar onboard CALIPSO are used in conjunction with the GEOS-Chem chemical transport model and NOAA's HYSPLIT trajectory model to document three aerosol export events from East Asia to the Arctic in the year 2007. During each of these events CALIOP sampled the pollution plumes multiple times over periods of five to seven days. Midlatitude cyclones lifted the pollution to the free troposphere with net diabatic heating of $\sim 5^{\circ} \mathrm{Cday}^{-1}$ and precipitation in this initial ascending stage. Rapid meridional transport to the Arctic took place at 3-7 km altitude, and was mediated by either a blocking high pressure system in the NW Pacific or a trough-ridge configuration. Once in the Arctic transport was nearly isentropic with slow subsidence and radiative cooling at a rate of $1-1.5^{\circ} \mathrm{Cday}^{-1}$. We find good agreement between modeled and observed plumes in terms of length, altitude, thickness and, within the measurement uncertainties, extinction coefficient. In one event the satellite algorithm misclassifies the aerosol layer as ice clouds as a result of the relatively high depolarization ratio (0.06), likely caused by a high dust component in the aerosol mixture. Using $500 \mathrm{hPa}$ geopotential height anomalies for these three events along with eight other export events observed by CALIOP in 2007-2009, we develop a meteorological index that captures $40-60 \%$ of the variance of Asian transport events to the Arctic in winter and spring. Simulations with the GEOS-Chem model show that 6 major export events from Asia to the Arctic occur each year, on average. The maximum probability for such events is during March-June, with a secondary maximum in October-November. During these events, Asian pollution and dust aerosols account for 50 $70 \%$ of the aerosol optical depth over the Siberian sector of the Arctic, compared to a mean background contribution of $33 \%$.
\end{abstract}

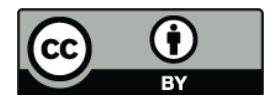

Correspondence to: M. Di Pierro (dipierro@atmos.washington.edu)

\section{Introduction}

Starting in the 1950s, weather reconnaissance flights over the Arctic have revealed the existence of a haze that could extend over vast areas (Mitchell, 1956). This phenomenon became later known as Arctic Haze. Chemical analyses of the particulate matter showed that the haze was predominantly composed of sulfate and organic matter in addition to smaller quantities of black carbon (BC), ammonium, nitrate, and dust aerosols, as well as heavy metals and condensed volatile organic carbon compounds (Quinn et al., 2002).

Arctic Haze has long been attributed to transport of pollution from mid-latitude sources (Shaw, 1995). Chemical transport models (CTMs) show the dominant role of Europe and Russia as sources of low-level aerosol pollutants to the Arctic, but also show that East Asian and North American aerosols make a significant contribution in the middle and upper troposphere during winter and spring (Klonecki et al., 2003; Koch and Hansen, 2005).

Transport to the Arctic is largely mediated by the Polar Dome, a tropospheric barrier of isentropic surfaces closing around the Arctic. If the transport is adiabatic, air parcels follow the northward sloping surfaces and necessarily have to ascend (Carlson, 1981). Also, following this argument, a warm air mass will ascend more than a cooler one when traveling from the mid-latitudes to the Arctic. Springtime transport of North American and East Asian sources to the Arctic generally occurs by export from the boundary layer in the warm conveyor belt of mid-latitude cyclones, followed by poleward transport along sloping isentropes in the free troposphere, and entrance into the polar dome from above by means of radiative cooling (Klonecki et al., 2003; Stohl, 2006). In contrast, northern Eurasian emissions tend to be transported at lower levels to the Arctic. Indeed, rapid lowlevel transport can be associated with a significant poleward retreat of the polar front in the presence of a blocking event or by prolonged flow over cold, snow-covered land masses

Published by Copernicus Publications on behalf of the European Geosciences Union. 
causing strong diabatic cooling (Iversen and Joranger, 1985; Klonecki et al., 2003; Stohl, 2006).

In a recent CTM inter-comparison study, Shindell et al. (2008) demonstrated that the relative importance of different regions as aerosol sources for the Arctic is consistent across models, but that the absolute concentrations vary significantly. These discrepancies are linked to uncertainties in model representations of aerosol physical and chemical processes, but also to model-to-model variations in transport in the middle and upper troposphere. The scarceness of Arctic observations in the free troposphere has hindered the evaluations of models in that region. While there have been a number of recent aircraft campaigns targeting the Arctic (TOPSE, ARCTAS, ARCPAC and POLARCAT), most took place in the North American or European sector of the Arctic. Thus the Siberian sector, where models predict a dominant influence of Asian aerosols, remains poorly characterized by observations.

In this study, we use Arctic observations of the vertical distribution of aerosols from the Cloud-Aerosol Lidar with Orthogonal Polarization (CALIOP) on board the CALIPSO satellite to examine three episodes of pollution export from East Asia to the Arctic, two during early spring and one in autumn. CALIOP has several advantages in the study of long-range transport of aerosols to the Arctic. Unlike passive satellite sensors (such as MODIS, MISR, PARASOL) it determines the precise vertical location of identified features and it can retrieve aerosol properties during both night and day, as well as over highly reflective ice and snow surfaces. The main limitations of CALIOP are that it only samples directly beneath the satellite (i.e. zero swath width) and that it can not detect aerosols located beneath optically thick clouds. In this paper, we combine CALIOP retrievals of aerosol attenuated backscatter and extinction, together with the GEOS-Chem model and backtrajectory calculations to track the transport pathway and evolution of these three Asian plumes. Section 2 presents a description of GEOSChem, CALIOP and the lagrangian trajectory model. The three case studies are presented in Sect. 3. A discussion of the meteorological conditions favoring export from East Asia to the Arctic follows in Sect. 4. Section 5 summarizes the results.

\section{Models and observations}

\subsection{GEOS-Chem model}

The GEOS-Chem global tropospheric chemistry model is driven by assimilated meteorological observations from the Goddard Earth Observing System (GEOS-5). The GEOS5 meteorological fields have a 3 to $6 \mathrm{~h}$ temporal resolution, with a native resolution of $0.5^{\circ} \times 0.667^{\circ}$ in the horizontal and 72 hybrid eta vertical levels, extending from the surface up to $0.01 \mathrm{hPa}(\sim 80 \mathrm{~km})$. For our simulations, we de- grade these fields to a $2^{\circ} \times 2.5^{\circ}$ horizontal resolution and 47 vertical levels. We use version v8-02-04 of GEOS-Chem (http://acmg.seas.harvard.edu/geos/).

We conduct a fully coupled aerosol-oxidant simulation (Bey et al., 2001; Martin et al., 2003; Park et al., 2004) for 2007-2009. This simulation was initialized with a 1-yr spin-up run. The aerosol simulation in GEOS-Chem represents the sulfate-nitrate-ammonium system (Park et al., 2004), organic carbon and black carbon (Park et al., 2003; Liao et al., 2007), sea salt (Alexander et al., 2005), and mineral dust (Fairlie et al., 2007), as an external mixture. The aerosol extinction and optical depth are calculated at $550 \mathrm{~nm}$ from Mie theory (Martin et al., 2003). This wavelength is close enough to CALIOP $532 \mathrm{~nm}$ channel to permit direct comparison between the two variables. The assumed dry aerosol mass extinction efficiencies are: $2.2 \mathrm{~m}^{2} \mathrm{~g}^{-1}$ for sulfate, $8 \mathrm{~m}^{2} \mathrm{~g}^{-1}$ for $\mathrm{BC}, 2.8 \mathrm{~m}^{2} \mathrm{~g}^{-1}$ for organic carbon, $2.4 \mathrm{~m}^{2} \mathrm{~g}^{-1}$ and $0.9 \mathrm{~m}^{2} \mathrm{~g}^{-1}$ for accumulation and coarse mode sea salt, respectively, and $3.1-0.16 \mathrm{~m}^{2} \mathrm{~g}^{-1}$ for dust depending on the size bin. We take into account aerosol growth as a function of the local relative humidity.

Global anthropogenic emissions are from the EDGAR 3.2FT2000 database (Olivier and Berdowski, 2001) for 2000. Over Asia, these emissions are overwritten with the emission inventory of Zhang et al. (2009) corresponding to the year 2006, with annual anthropogenic and biofuel emissions of $47.1 \mathrm{Tg} \mathrm{SO}, 2.97 \mathrm{Tg} \mathrm{BC}$, and $6.57 \mathrm{Tg}$ organic carbon. Dust emissions are based on a dust mobilization scheme that takes into account seasonal devegetation (Zender et al., 2003). Biomass burning emissions are taken from the GFEDv2 monthly inventory (Van der Werf et al., 2006). Aerosol dry deposition velocities are computed with a standard resistance-in-series scheme described by Wang et al. (1998). Wet deposition takes into account scavenging in convective updrafts in addition to in-cloud and below-cloud scavenging (Liu et al., 2001).

We also conduct a sensitivity simulation, where anthropogenic sources of aerosols and their precursors are turned off over Asia (defined here as $70-180^{\circ} \mathrm{E} ; 8-70^{\circ} \mathrm{N}$ ). In this simulation, we also turned off Asian dust sources in the region $42-152.5^{\circ} \mathrm{E}, 20-88^{\circ} \mathrm{N}$. We infer the Asian contribution to the AOD by subtraction between the standard simulation and the sensitivity simulation with Asian anthropogenic aerosol sources and dust sources turned off. The resulting AOD will be referred to as "Asian AOD". In the discussion we will also refer to the anthropogenic sulfate component of the Asian AOD as "Asian Sulfate AOD", and to the Asian AOD dust component as "Asian Dust AOD".

For comparison to CALIOP observations, we sample the model along the CALIPSO orbit tracks, extracting 1-h time resolution tracer fields obtained from the original fields by linear interpolation. Thus, the observed and model scenes always coincide to within thirty minutes. 


\subsection{CALIOP lidar measurements}

The CALIPSO satellite was launched on 28 April 2006 and is part of the sun-synchronous A-train constellation of satellites, which orbits at $705 \mathrm{~km}$ a m.s.l. at an inclination of $98^{\circ}$, and completes 14.55 orbits a day crossing the equator at 01:30 p.m. LT. The CALIOP lidar is the main instrument on board CALIPSO. The lidar pulse is simultaneously emitted at $532 \mathrm{~nm}$ and $1064 \mathrm{~nm}$, providing vertically resolved attenuated backscatter profiles of the atmosphere at both wavelengths. A polarization beam splitter allows measurements of the parallel and perpendicular components of the $532 \mathrm{~nm}$ return (Winker et al., 2004). The two channels and polarization information are used to discriminate between clouds and aerosols. CALIOP's vertical resolution is $30-60 \mathrm{~m}$ in the troposphere. The horizontal resolution of a single lidar shot is $333 \mathrm{~m}$. However, a single atmospheric return signal is noisy, so consecutive profiles are averaged over $5-80 \mathrm{~km}$ to increase the signal-to-noise ratio and allow retrieval of faint features, such as aerosol layers far from their source region (Vaughan et al., 2004). Nighttime retrievals are characterized by a higher lidar signal-to-noise ratio compared to daytime retrievals, thus higher accuracy is achieved at night in terms of locating the boundaries of the layers and retrieving optical properties.

The measured Level-1 attenuated return signal is analyzed by three consecutive algorithms, which locate the feature, classify it into cloud or aerosol, and solve for its optical properties (Vaughan et al., 2004; Winker et al., 2009; Young and Vaughan, 2009). The results are archived in Level-2 Layer products and Profile products. The Level-2 Layer products contain information on the spatial distribution (i.e. top and bottom of individual features) and integrated optical properties of all aerosol and cloud features detected. In the Level-2 Profile products, each atmospheric column is vertically resolved for its optical properties at a vertical resolution of 60$120 \mathrm{~m}$ in the troposphere.

The performance of the aerosol-cloud discrimination algorithm has been assessed on a global basis based on expert manual classification performed over one day of data (Liu et al., 2009). A percentage of 3-4\% of aerosol layers are erroneously classified as clouds, which is roughly comparable to the percentage of cloud layers erroneously classified as aerosols. Under daytime conditions, misclassification of aerosols as clouds is more frequent than at nighttime, whereas the opposite occurs for the misclassification of clouds as aerosols. These issues will be addressed in more detail over the Arctic in this paper (Sect. 3.2.3).

In our study, we use version 2.01 Level-2 Cloud (5-km) and Aerosol (40-km) Profile products to perform comparisons between CALIOP and GEOS-Chem aerosol extinction profiles. The plume optical properties are extracted from 5$\mathrm{km}$ Aerosol Layer products. The reported uncertainty in extinction coefficient is reported to be $\pm 40 \%$ based on a $30 \%$ lidar ratio uncertainty (see http://www-calipso.larc.nasa.gov/ products/). After our analysis was completed, a more recent version of the CALIOP retrieval became available (v3.01). We have repeated our analysis with this more recent version in one case study, finding nearly identical results (see Sect. 3.1).

\subsection{HYSPLIT trajectory model}

We use the NOAA Air Resources Laboratory Lagrangian Trajectory model HYSPLIT version 4.9 (Draxler and Hess, 2004) to calculate backtrajectories and identify the source of the aerosols observed over the Arctic. In our calculations, HYSPLIT is driven by the NCEP (National Centers for Environmental Prediction) GDAS (Global Data Assimilation System) meteorological fields with a 3 hourly temporal resolution, $1^{\circ} \times 1^{\circ}$ horizontal resolution and 23 vertical levels from 1000 to $20 \mathrm{hPa}$. The trajectories include 3-D turbulent components to simulate dispersion (Draxler and Hess, 2004). We employed model vertical velocity fields rather than constraining the transport to occur on isentropic surfaces. The crosssection of aerosol plumes observed by CALIOP is sampled by taking the mid-point of each 5 -km horizontal layer belonging to the plume. A random subset of 50 points is then extracted from the observed plume and backtrajectories are run for 10 days.

\section{Case studies}

We visually inspected CALIOP Level-2 observations for the year 2007 over the Arctic using the GEOS-Chem model simulation to locate large Asian aerosol transport events. We then selected three events during which the aerosol plumes were intercepted multiple times by the CALIPSO orbit tracks: 28 February-4 March; 12-19 March and 2027 October 2007.

\subsection{February-4 March 2007 pollution export episode}

This event was the most intense of the three presented here. Due to the large horizontal extent of the aerosol pollution plume (spanning more than $100^{\circ}$ longitude), the CALIPSO orbits intercepted it 23 times over this 5-day period.

\subsubsection{Morphology and optical properties of the observed haze layers}

Figure 1 shows the locations of the haze layers observed by CALIOP during the 28 February-3 March period. The CALIPSO orbits are drawn with a dashed line and their segments in the haze layer are in red. The layers were first observed over the East Siberian Arctic sector on 28 February , and then slowly drifted east to the North American sector. Table 1 presents a summary of the latitude/longitude range, height, aerosol optical depth (AOD), integrated volume depolarization ratio (IVDR) and integrated attenuated 

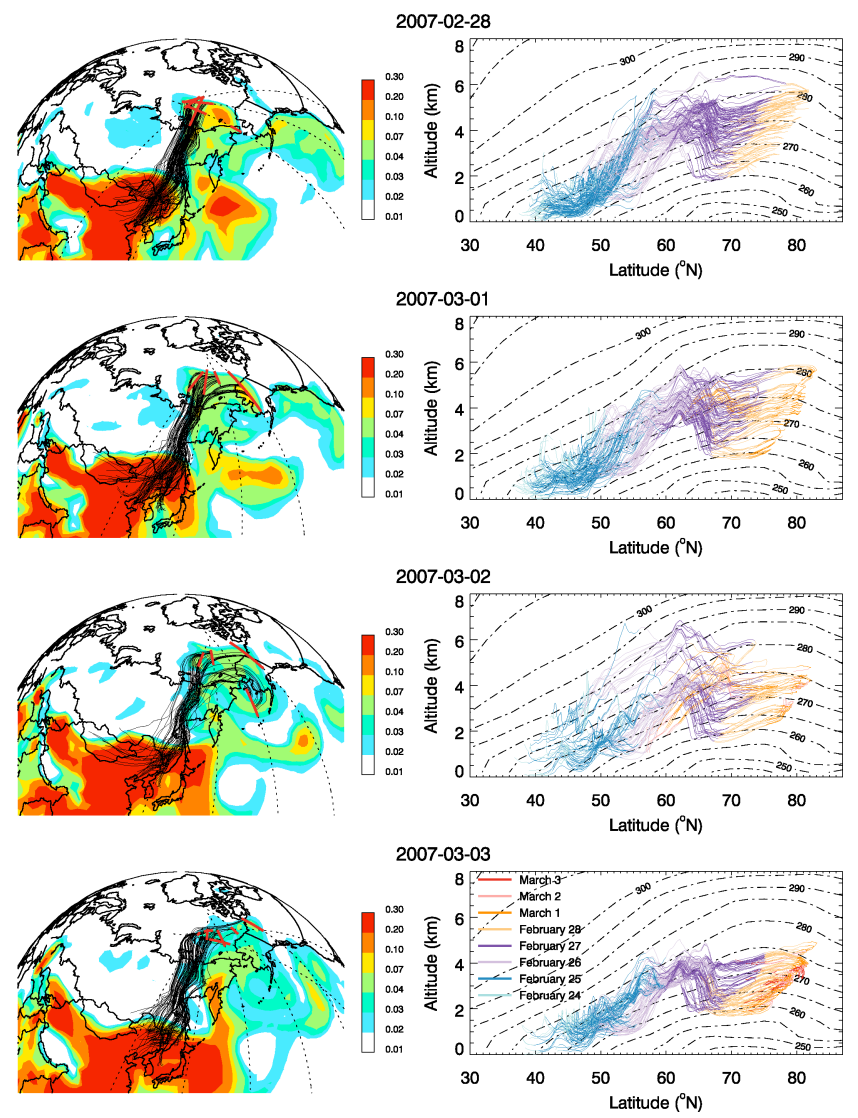

Fig. 1. 28 February-3 March 2007 Arctic haze event. Left column: daily Asian AOD (550 nm) calculated with GEOS-Chem. CALIPSO orbits are indicated by dashed lines and the parts of the orbit where the haze layers are observed are shown in red. Backtrajectories corresponding to the observed aerosol layers are shown in black, starting with 4-day backtrajectories on 28 February, and incremented by $24 \mathrm{~h}$ for each subsequent day. Right column: height (altitude above mean sea level) evolution as a function of latitude for backtrajectories shown on the left panel. The backtrajectories are color-coded based on the date (see legend on bottom panel). The potential temperature surfaces (dashed lines) are zonally averaged between $120^{\circ} \mathrm{E}$ and $150^{\circ} \mathrm{W}$ and temporally averaged between 25 February, $0 \mathrm{Z}$ and the time the last plume was observed for each day.

color ratio (ratio between attenuated backscatter at $1064 \mathrm{~nm}$ and $532 \mathrm{~nm}$, henceforth simply referred to as color ratio) for the 23 plume cross sections observed by CALIOP during this event. Figure 2 displays a subset of five CALIOP and GEOSChem aerosol extinction cross sections of the haze event. The aerosol layers appear as thin elongated features ranging in thickness from 500 to $2000 \mathrm{~m}$, and individual segments had a length of $160 \mathrm{~km}$ to $1845 \mathrm{~km}$ (Table 1). The altitude of the features ranged from $1.5-4.5 \mathrm{~km}$ altitude at lower latitudes $\left(60-70^{\circ} \mathrm{N}\right)$ increasing to $2-6.5 \mathrm{~km}$ poleward of $70^{\circ} \mathrm{N}$.

The ascending shape of the aerosol plumes is characteristic of transport along sloping isentropes. The northward tilt of the aerosol layers is consistent with the local configuration of potential temperature surfaces (dashed lines in Fig. 2). The tilt is higher than the potential temperature surface slope in some instances, e. g. panel c in Fig. 2, indicating that various parts of the plume were emitted from sources at different potential temperatures and also underwent different histories of diabatic processes. In the case of panel b (Fig. 2), the lack of tilt is associated with a local flattening of the isentropes.

By integrating the CALIOP extinction over the length and height of individual plumes, we find AODs ranging from 0.01 to 0.1 , with a mean of 0.037 for all observations (Table 1). If we integrate over the entire vertical column $(0-10 \mathrm{~km})$ the mean AOD increases to 0.044 . The plume displays fairly uniform values of IVDR, with most values below 0.03 , indicating small particles and relatively small amounts of dust. Indeed, because of their large size and non-sphericity, dust aerosols exhibit the highest depolarization ratio (IVDR $>0.06$ ) of all aerosol species, while other aerosols have a much lower depolarization ratio (Liu et al., 2008). Values of the color ratio (0.21-0.36) are also small, indicating sub-micron size, typical of pollution aerosols or smoke.

Our results, obtained with version 2.01 of the CALIOP retrieval, do not change much when compared with the more recent version, 3.01. With v3.01, mean plume AOD is 0.030 (compared to 0.037 for v2.01), with mean IVDR 0.029 (0.03 for v2.01) and Color Ratio 0.24 ( 0.26 for v2.01). We find that the aerosol/cloud classification is the same for both versions, except for 2 out of the 23 CALIOP cross sections, where v3.01 classifies the features as mostly clouds, while v2.01 classifies them as aerosols.

\subsubsection{Asian origin and meteorology of the event}

The backtrajectories corresponding to each observed aerosol layer are shown in Fig. 1. We are only displaying trajectories that originate in the boundary layer (defined here as reaching an altitude below $1500 \mathrm{~m}$ ), which account for roughly half of the backtrajectories. The plume originated from the boundary layer over NE China 4-8 days prior to observations. In addition, $6 \%$ of the trajectories come from the Gobi desert. The Asian origin of the haze event is confirmed by the GEOS-Chem Asian AOD simulation, with observed plumes located over areas with enhancements in Asian AOD (Fig. 1).

The observed airmasses ascended to $4-7 \mathrm{~km}$ altitude in $24 \mathrm{~h}$ and most of the ascent took place between 25 February $12 \mathrm{Z}$ and 27 February $0 \mathrm{Z}$ (Fig. 1, right panels). Potential temperature and precipitation computed along the trajectories shows that the initial stage of diabatic transport was associated with precipitation to the ground. This was followed by dry transport; with gradual ascent following isentropic surfaces poleward of $67^{\circ} \mathrm{N}$. We find that the departure from isentropy is due to radiative cooling at a rate of $\sim 1.5^{\circ} \mathrm{C} \mathrm{day}^{-1}$, in agreement with previous studies (Curry, 1983; Carlson, 1981). The rapid altitude variations for backtrajectories between $55^{\circ} \mathrm{N}$ and $60^{\circ} \mathrm{N}$ are associated with 

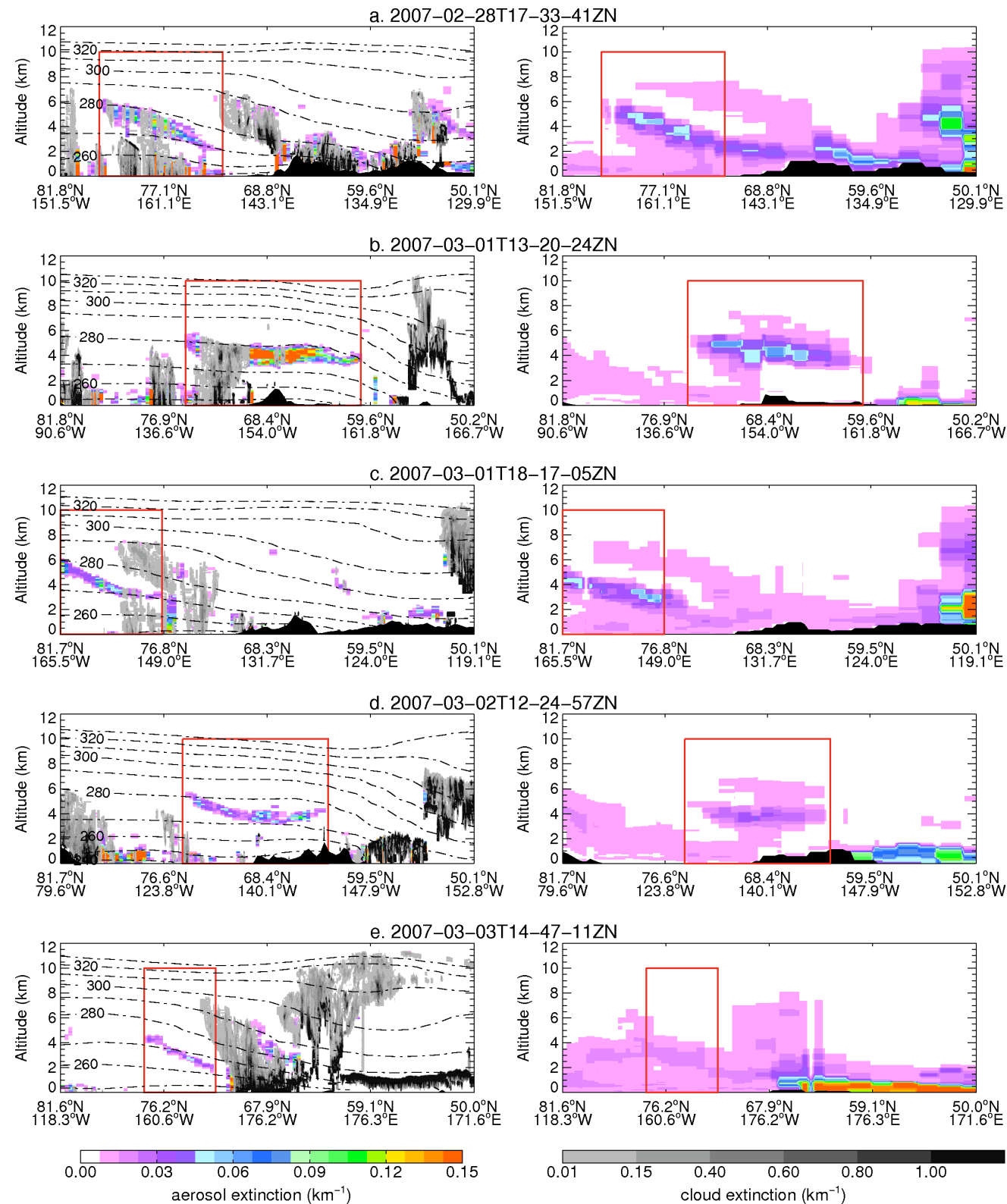

Fig. 2. Aerosol extinction comparison between CALIOP (L2 profile data, left) and GEOS-Chem (right). Five scenes were chosen among the 23 East Asian plumes observed by CALIOP during the 28 February-4 March period. Aerosol extinctions are plotted in color and cloud extinctions observed by CALIPSO are in gray. The red box delimits the aerosol layers that have an East Asian origin (see text). Potential temperature contours are shown with dashed-dotted lines on the left panels. The text on top of each panel is the CALIOP file identifier.

orographic effects as parcels are traveling above the mountain ranges of southeastern Siberia at low altitudes.

Subsidence within the Arctic basin could be seen only for the last $16 \mathrm{~h}$ of the last plume on 4 March at 15:30 UTC, with a subsidence rate of $\sim 1 \mathrm{~cm} \mathrm{~s}^{-1}$. No plume was observed to reach the surface. It is likely that the plumes dissipated to the point where their backscatter fell below CALIOP detection threshold even if subsidence continued.
This export event was triggered by a mid-latitude cyclone that formed on 21 February North of the Black Sea and began to travel eastward over continental Asia. On 23 February at 12:00 UTC, the cyclone reached its maximum intensity $(987 \mathrm{hPa})$. It then began to weaken as it continued on its eastward route. A secondary cyclogenesis occurred as the low pressure center passed over the Altai mountain range, a region of active lee cyclogenesis (Chen et al., 1991). The pressure minimum decreased for two consecutive 6-h periods and reached a new minimum on 24 February at 12:00 UTC. 
Table 1. Summary of the 23 Arctic aerosol layers observed by CALIOP for the 28 February-4 March 2007 case study.

\begin{tabular}{|c|c|c|c|c|c|c|c|c|c|}
\hline \multirow{3}{*}{$\begin{array}{l}\text { Date }^{\mathrm{a}} \\
02-2817.33 \mathrm{~N}\end{array}$} & & & \multicolumn{5}{|c|}{ CALIOP } & \multicolumn{2}{|c|}{ GEOS-Chem } \\
\hline & \multicolumn{2}{|c|}{$\begin{array}{l}\text { Location of endpoints } \\
\text { Latitude; Longitude }\end{array}$} & $\begin{array}{l}\text { Length } \\
(\mathrm{km})\end{array}$ & $\begin{array}{c}\text { Mean } \\
\text { Altitude }(\mathrm{km})\end{array}$ & IVDR $^{\mathrm{b}}$ & $\begin{array}{l}\text { Color } \\
\text { Ratio }\end{array}$ & $\begin{array}{c}\text { AOD } \\
{\text { (plume } \mid \text { column })^{\mathrm{c}}}^{\text {(plume }}\end{array}$ & $\begin{array}{c}\text { AOD w/o TH } \\
\text { (plume | column) }\end{array}$ & $\begin{array}{c}\text { AOD w/ TH } \\
\text { (plume | column) }\end{array}$ \\
\hline & $72.5^{\circ} \mathrm{N} ; 148.8^{\circ} \mathrm{E}$ & $80.9^{\circ} \mathrm{N} ; 174.0^{\circ} \mathrm{W}$ & 1275 & 3.8 & 0.027 & 0.26 & $0.03 \mid 0.05$ & $0.08 \mid 0.13$ & $0.06 \mid 0.08$ \\
\hline $02-2819.12 \mathrm{~N}$ & $79.3^{\circ} \mathrm{N} ; 146.7^{\circ} \mathrm{E}$ & $81.8^{\circ} \mathrm{N} ; 175.7^{\circ} \mathrm{W}$ & 720 & 5.3 & 0.029 & 0.26 & $0.03 \mid 0.03$ & $0.03 \mid 0.10$ & $0.02 \mid 0.05$ \\
\hline $02-2819.59 \mathrm{D}^{\mathrm{e}}$ & $80.9^{\circ} \mathrm{N} ; 169.8^{\circ} \mathrm{W}$ & $81.8^{\circ} \mathrm{N} ; 161.9^{\circ} \mathrm{E}$ & 475 & 5.7 & 0.031 & 0.36 & $0.04 \mid 0.05$ & $0.02 \mid 0.08$ & $0.02 \mid 0.04$ \\
\hline $02-2820.51 \mathrm{~N}^{\mathrm{e}}$ & $81.4^{\circ} \mathrm{N} ; 145.3^{\circ} \mathrm{E}$ & $81.8^{\circ} \mathrm{N} ; 161.9^{\circ} \mathrm{E}$ & 235 & 5.2 & 0.032 & 0.29 & $0.03 \mid 0.03$ & $0.05 \mid 0.11$ & $0.04 \mid 0.07$ \\
\hline $02-2821.37 \mathrm{D}$ & $77.1^{\circ} \mathrm{N} ; 169.6^{\circ} \mathrm{W}$ & $81.8^{\circ} \mathrm{N} ; 141.8^{\circ} \mathrm{E}$ & 1065 & 5.1 & 0.028 & 0.32 & $0.04 \mid 0.04$ & $0.06 \mid 0.12$ & $0.06 \mid 0.07$ \\
\hline $02-2823.16 \mathrm{D}$ & $64.5^{\circ} \mathrm{N} ; 172.1^{\circ} \mathrm{W}$ & $67.9^{\circ} \mathrm{N} ; 175.5^{\circ} \mathrm{W}$ & 400 & 3.7 & 0.065 & 0.34 & $0.01 \mid 0.01$ & $0.01 \mid 0.08$ & $0.01 \mid 0.03$ \\
\hline $02-2823.16 \mathrm{D}$ & $75.2^{\circ} \mathrm{N} ; 171.8^{\circ} \mathrm{E}$ & $80.1^{\circ} \mathrm{N} ; 148.3^{\circ} \mathrm{E}$ & 765 & 3.7 & 0.021 & 0.31 & $0.04 \mid 0.04$ & $0.06 \mid 0.12$ & $0.06 \mid 0.07$ \\
\hline $03-0113.20 \mathrm{~N}$ & $60.1^{\circ} \mathrm{N} ; 161.5^{\circ} \mathrm{W}$ & $75.3^{\circ} \mathrm{N} ; 141.6^{\circ} \mathrm{W}$ & 1845 & 4.0 & 0.044 & 0.27 & $0.10 \mid 0.11$ & $0.07 \mid 0.10$ & $0.06 \mid 0.06$ \\
\hline $03-0114.59 \mathrm{~N}$ & $75.2^{\circ} \mathrm{N} ; 166.5^{\circ} \mathrm{W}$ & $79.1^{\circ} \mathrm{N} ; 151.1^{\circ} \mathrm{W}$ & 560 & 4.3 & 0.024 & 0.24 & $0.02 \mid 0.02$ & $0.05 \mid 0.10$ & $0.04 \mid 0.06$ \\
\hline $03-0116.38 \mathrm{~N}$ & $74.6^{\circ} \mathrm{N} ; 167.2^{\circ} \mathrm{E}$ & $81.3^{\circ} \mathrm{N} ; 153.9^{\circ} \mathrm{W}$ & 1120 & 3.6 & 0.026 & 0.24 & $0.01 \mid 0.02$ & $0.07 \mid 0.11$ & $0.05 \mid 0.06$ \\
\hline $03-0118.17 \mathrm{~N}$ & $76.9^{\circ} \mathrm{N} ; 149.4^{\circ} \mathrm{E}$ & $81.8^{\circ} \mathrm{N} ; 164.4^{\circ} \mathrm{W}$ & 1040 & 4.1 & 0.024 & 0.25 & $0.04 \mid 0.04$ & $0.06 \mid 0.11$ & $0.05 \mid 0.06$ \\
\hline $03-0212.24 \mathrm{~N}$ & $63.1^{\circ} \mathrm{N} ; 145.3^{\circ} \mathrm{W}$ & $74.9^{\circ} \mathrm{N} ; 128.7^{\circ} \mathrm{W}$ & 1440 & 4.0 & 0.025 & 0.22 & $0.02 \mid 0.02$ & $0.04 \mid 0.08$ & $0.03 \mid 0.03$ \\
\hline $03-0214.03 \mathrm{~N}$ & $54.1^{\circ} \mathrm{N} ; 175.7^{\circ} \mathrm{W}$ & $63.1^{\circ} \mathrm{N} ; 170.1^{\circ} \mathrm{W}$ & 1040 & 2.1 & 0.052 & 0.28 & $0.08 \mid 0.08$ & $0.03 \mid 0.09$ & $0.01 \mid 0.04$ \\
\hline $03-0215.42 \mathrm{~N}$ & $75.5^{\circ} \mathrm{N} ; 176.5^{\circ} \mathrm{W}$ & $79.8^{\circ} \mathrm{N} ; 156.7^{\circ} \mathrm{W}$ & 660 & 3.5 & 0.028 & 0.26 & $0.01 \mid 0.05$ & $0.06 \mid 0.09$ & $0.03 \mid 0.04$ \\
\hline $03-0217.21 \mathrm{~N}$ & $77.2^{\circ} \mathrm{N} ; 164.2^{\circ} \mathrm{E}$ & $80.8^{\circ} \mathrm{N} ; 171.6^{\circ} \mathrm{W}$ & 640 & 3.5 & 0.027 & 0.27 & $0.02 \mid 0.03$ & $0.05 \mid 0.10$ & $0.04 \mid 0.05$ \\
\hline $03-0311.29 \mathrm{~N}$ & $64.1^{\circ} \mathrm{N} ; 130.6^{\circ} \mathrm{W}$ & $71.0^{\circ} \mathrm{N} ; 122.7^{\circ} \mathrm{W}$ & 820 & 3.6 & 0.029 & 0.26 & $0.04 \mid 0.04$ & $0.04 \mid 0.07$ & $0.02 \mid 0.02$ \\
\hline $03-0313.08 \mathrm{~N}$ & $71.6^{\circ} \mathrm{N} ; 146.4^{\circ} \mathrm{W}$ & $74.3^{\circ} \mathrm{N} ; 141.0^{\circ} \mathrm{W}$ & 340 & 3.4 & 0.019 & 0.21 & $0.01 \mid 0.03$ & $0.04 \mid 0.09$ & $0.04 \mid 0.05$ \\
\hline $03-0314.47 \mathrm{~N}$ & $72.3^{\circ} \mathrm{N} ; 169.8^{\circ} \mathrm{W}$ & $77.6^{\circ} \mathrm{N} ; 155.6^{\circ} \mathrm{W}$ & 700 & 3.1 & 0.020 & 0.21 & $0.01 \mid 0.01$ & $0.04 \mid 0.08$ & $0.02 \mid 0.03$ \\
\hline $03-0316.26 \mathrm{~N}$ & $77.4^{\circ} \mathrm{N} ; 179.1^{\circ} \mathrm{E}$ & $80.3^{\circ} \mathrm{N} ; 163.8^{\circ} \mathrm{W}$ & 480 & 3.5 & 0.026 & 0.29 & $0.02 \mid 0.02$ & $0.02 \mid 0.08$ & $0.02 \mid 0.04$ \\
\hline $03-0318.05 \mathrm{~N}$ & $80.2^{\circ} \mathrm{N} ; 171.4^{\circ} \mathrm{E}$ & $80.9^{\circ} \mathrm{N} ; 179.2^{\circ} \mathrm{E}$ & 160 & 3.3 & 0.029 & 0.23 & $0.01 \mid 0.02$ & $0.01 \mid 0.08$ & $0.00 \mid 0.02$ \\
\hline $03-0320.30 \mathrm{D}$ & $78.7^{\circ} \mathrm{N} ; 159.7^{\circ} \mathrm{W}$ & $80.4^{\circ} \mathrm{N} ; 172.5^{\circ} \mathrm{W}$ & 320 & 3.6 & 0.032 & 0.29 & $0.01 \mid 0.02$ & $0.02 \mid 0.07$ & $0.01 \mid 0.02$ \\
\hline $03-0322.09 \mathrm{D}$ & $71.7^{\circ} \mathrm{N} ; 163.8^{\circ} \mathrm{W}$ & $77.1^{\circ} \mathrm{N} ; 177.5^{\circ} \mathrm{W}$ & 720 & 2.8 & 0.010 & 0.24 & $0.01 \mid 0.01$ & $0.03 \mid 0.07$ & $0.02 \mid 0.03$ \\
\hline $03-0410.33 \mathrm{~N}$ & $61.0^{\circ} \mathrm{N} ; 119.1^{\circ} \mathrm{W}$ & $65.8^{\circ} \mathrm{N} ; 115.2^{\circ} \mathrm{W}$ & 560 & 3.9 & 0.029 & 0.22 & $0.05 \mid 0.05$ & $0.04 \mid 0.07$ & $0.02 \mid 0.02$ \\
\hline $03-0415.30 \mathrm{~N}$ & $77.7^{\circ} \mathrm{N} ; 165.9^{\circ} \mathrm{W}$ & $78.7^{\circ} \mathrm{N} ; 160.9^{\circ} \mathrm{W}$ & 160 & 2.9 & 0.026 & 0.27 & $0.02 \mid 0.02$ & $0.02 \mid 0.06$ & $0.00 \mid 0.00$ \\
\hline Mean $^{\mathrm{f}}$ & - & - & 730 & 3.8 & $0.030 \pm 0.011$ & $0.26 \pm 0.04$ & $0.037 \mid 0.044$ & $0.049 \mid 0.093$ & $0.036 \mid 0.048$ \\
\hline
\end{tabular}

${ }^{a}$ Dates are given as MM-DD UTC time (hh.mm). N or D indicates night or day observations. ${ }^{\mathrm{b}}$ Integrated Volume Depolarization Ratio (IVDR). ${ }^{\mathrm{c}}$ The first number corresponds to the observed AOD in the plume only while the second number indicates the AOD for the entire column (0-10 km). These numbers are obtained by first regridding the CALIOP observations to the horizontal and vertical resolution of GEOS-Chem. ${ }^{\mathrm{d}}$ The two GEOS-Chem columns correspond to the AOD without threshold (w/o TH) and with threshold (w/TH) based on the CALIOP sensitivity. ${ }^{\mathrm{e}}$ The third haze layer was observed under daytime and nighttime conditions so it straddles 2 files. ${ }^{\mathrm{f}}$ All mean aerosol properties are weighted by the length of the cross-section.

Figure 3 (left panels) shows the modeled Asian AOD, $500 \mathrm{hPa}$ geopotential heights and $500 \mathrm{hPa}$ winds for 25 28 February . Sea level pressure and precipitation are displayed on the right panels. Geopotential heights and sea level pressure are from the NCEP-NCAR Reanalysis (Kalnay et al., 1996), whereas precipitation is from GEOS-5. The secondary cyclogenesis is reflected in the mid-tropospheric deepening of a secondary wave that becomes a full trough on 26 February, as shown in the two top panels of Fig. 3.

The low pressure center (marked with an L in the top right panel of Fig. 3) began to manifest its influence upon NE China on 25 February, when persistent warm advection anticipated the passage of a cold front. In the early stages of the export the AOD enhancement is found on the east side of the surface low. Surface convergence around the low on 25 February provides the ascending motion by means of a warm conveyor belt, which lifts the pollution to the middle troposphere.

Both the trajectories and GEOS-5 meteorological fields indicate that precipitation was associated with this lifting between 25 February and 27 February, south of $65^{\circ} \mathrm{N}$. As a result of this precipitation, the aerosol-laden air mass underwent strong scavenging associated with transport in the low pressure system. By contrasting the GEOS-Chem AOD for individual aerosol species over the Arctic with the corresponding values over the source region, we estimate export efficiencies of $\sim 15 \%$ for sulfate, $\sim 20 \%$ for BC, and $30-40 \%$ for dust.

The subsequent rapid poleward transport of the plume is associated with a NW Pacific blocking high pressure system ( $\mathrm{H}$ in bottom left panels, Fig. 3), which began to form at the end of February and persisted until mid-March. This high lead to a split Asian outflow, with one branch moving poleward, and the other branch going East out to the Pacific.

\subsubsection{Comparison between observed and modeled haze layers.}

The model generally reproduces both the horizontal and vertical location of the observed aerosol layer (Fig. 2, Table 1). However, while the boundaries of the haze layer are well defined in the observations, they appear to be more spreadout in the model. This could be due to the coarser horizontal and vertical resolution of the model. The difference between model and observations could also be associated with the sensitivity of the CALIOP instrument. Winker et al. (2009) report a $532 \mathrm{~nm}$ backscatter sensitivity threshold for CALIOP nighttime retrievals at $80 \mathrm{~km}$ horizontal averaging of $2 \times 10^{-4} \mathrm{~km}^{-1} \mathrm{sr}^{-1}$ at $10 \mathrm{~km}$ altitude increasing to $4 \times 10^{-4} \mathrm{~km}^{-1} \mathrm{sr}^{-1}$ at the surface. We take into account this altitude-dependent sensitivity by setting to zero model backscatter coefficients below the CALIOP detection 

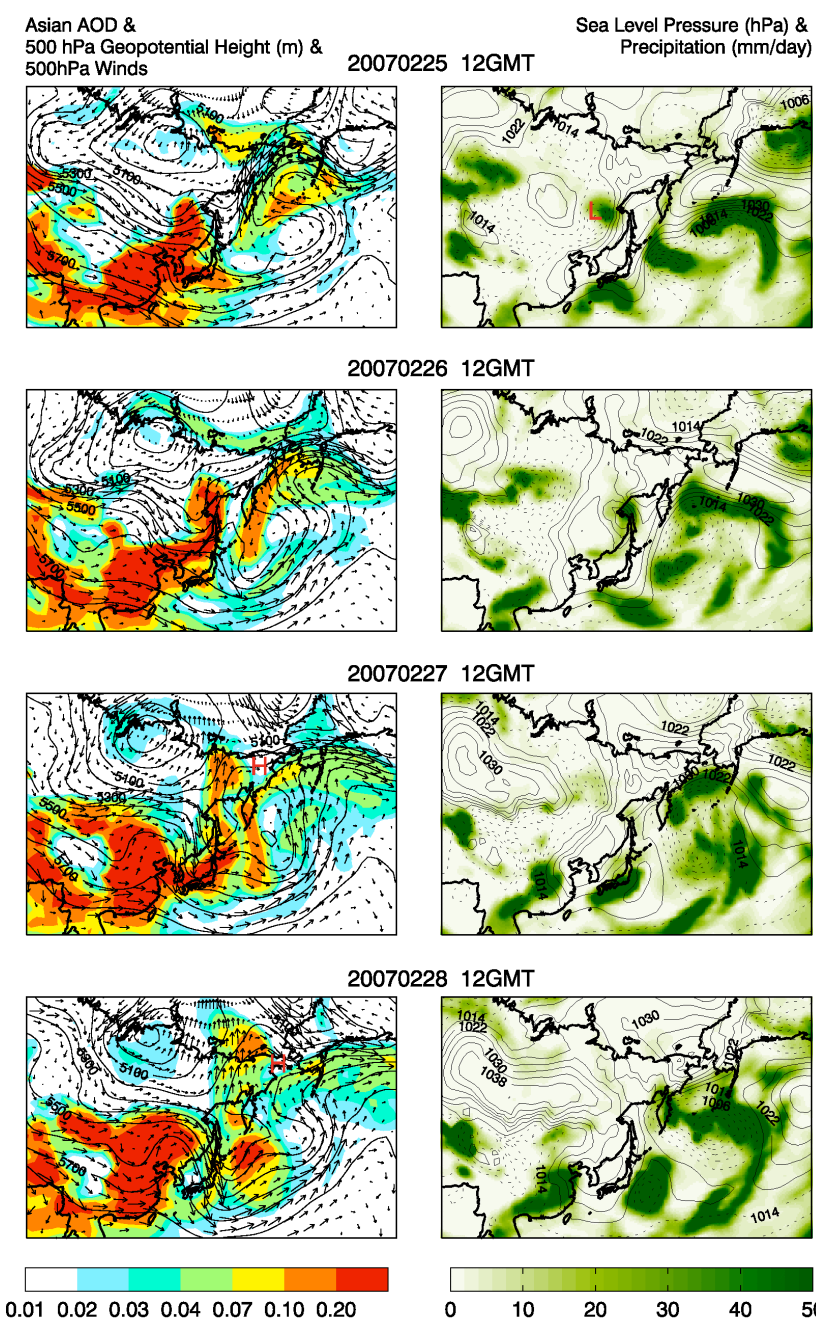

Asian AOD

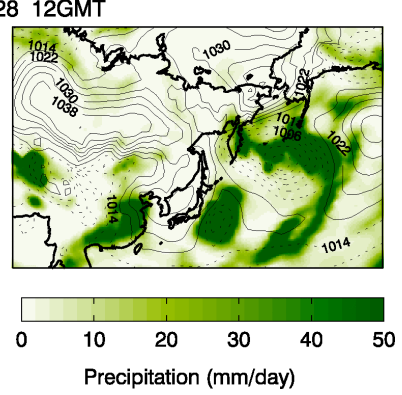

Fig. 3. Left panel: $500 \mathrm{hPa}$ geopotential height (black contours) and corresponding wind vector evolution during the initial period of aerosol export, together with GEOS-Chem Asian AOD (in color) for 25-28 February 2007. Right panel: Sea level pressure (contours) and precipitation (green). SLP contours $(4 \mathrm{hPa})$ are dashed when SLP is below $1014 \mathrm{hPa}$. H indicates the blocking high pressure system; L shows the location of the low pressure center.

threshold (Fig. 4, right panels). We also grid CALIOP observation onto the model grid (Fig. 4, left panels). This more direct comparison leads to sharply defined boundaries in the model plumes, in better agreement with CALIOP.

Figure 5 shows a comparison between satellite-retrieved and modeled mean extinction profiles averaged over the cloud free regions within the red box in Fig. 4. We applied the CALIOP sensitivity threshold to the model extinction. In performing the horizontal averaging for both model and observations, we excluded atmospheric columns below the top of the CALIOP-detected clouds. The model generally captures the layer height and extinction observed by
CALIOP. As summarized in Table 1, the model plume average AOD (0.037) is in good agreement with observations (0.036). For the $0-10 \mathrm{~km}$ column, the observed and modeled AOD are 0.044 and 0.048 , respectively. If we do not take into account the altitude dependent sensitivity, we find that the model overestimates observations by $40-100 \%$ (model plume AOD: 0.049, model column AOD: 0.093, Table 1).

The dominant aerosol species in the model is sulfate ( $>80 \%$ of the total extinction), while dust accounts for most of the remaining extinction (see Fig. 5). This is consistent with the low IDVR observed by CALIOP for this event. It is also consistent with the CALIOP aerosol classification for the observed layers, with $60 \%$ of the layers classified as "clean continental", $20 \%$ as "dust", $10 \%$ as polluted continental, and 5\% as smoke. In the model, Asian aerosol sources account for $40 \%$ of the total column AOD and $65 \%$ of the extinction within the plume.

\section{$3.2 \quad 12-19$ March 2007 export episode}

\subsubsection{Morphology and optical properties of the observed haze layers}

The first haze layer of this second export episode was observed by CALIOP on 12 March 2007 at 17:59 UTC. Thirtysix other layers were observed over the following 7 days, until 19 March (Table 2, Fig. 6). The aerosol layers are initially detected at $70-82^{\circ} \mathrm{N}$ above the East Siberian sector of the Arctic, then slowly move towards the N. American sector remaining at a mean altitude of 3-4 km. The mean thickness of the layers is $3 \mathrm{~km}$, with lengths ranging from 300 to $1400 \mathrm{~km}$.

The depolarization ratio of these layers is often in excess of 0.06 (Table 2), indicating a strong dust component. We note that daytime (D) and nighttime $(\mathrm{N})$ retrievals of IVDR and color ratio differ at $99 \%$ significance level, with nighttime values being systematically lower (IVDR: 0.051 for $\mathrm{N}$ and 0.067 for $\mathrm{D}$; color ratio: 0.25 for $\mathrm{N}$ and 0.32 for $\mathrm{D}$, Table 2). Ice crystals may be responsible for the high depolarization ratio, but we rule out this possibility because the IVDR demonstrates remarkable constancy spatially and temporally, and the features persist for several days.

\subsubsection{Meteorology}

The event started with strongly descending northwesterly cyclonic flow from the Mongolian Plateau to the Sea of Japan on 7-8 March 2007. This flow mobilized large amounts of dust, which then mixed in with pollution aerosols from NE China and accumulated over the Sea of Japan. On 10 March, 12:00 UTC (Fig. 7, top panels), the GEOS-Chem model shows high Asian AOD values over the Sea of Japan. This is confirmed by observations from the MODIS instrument onboard Terra (not shown). The formation of a cyclone over the NE coast of China on 10 March (labeled C in Fig. 7, right panels) led to the export of the pollution-dust mixture 

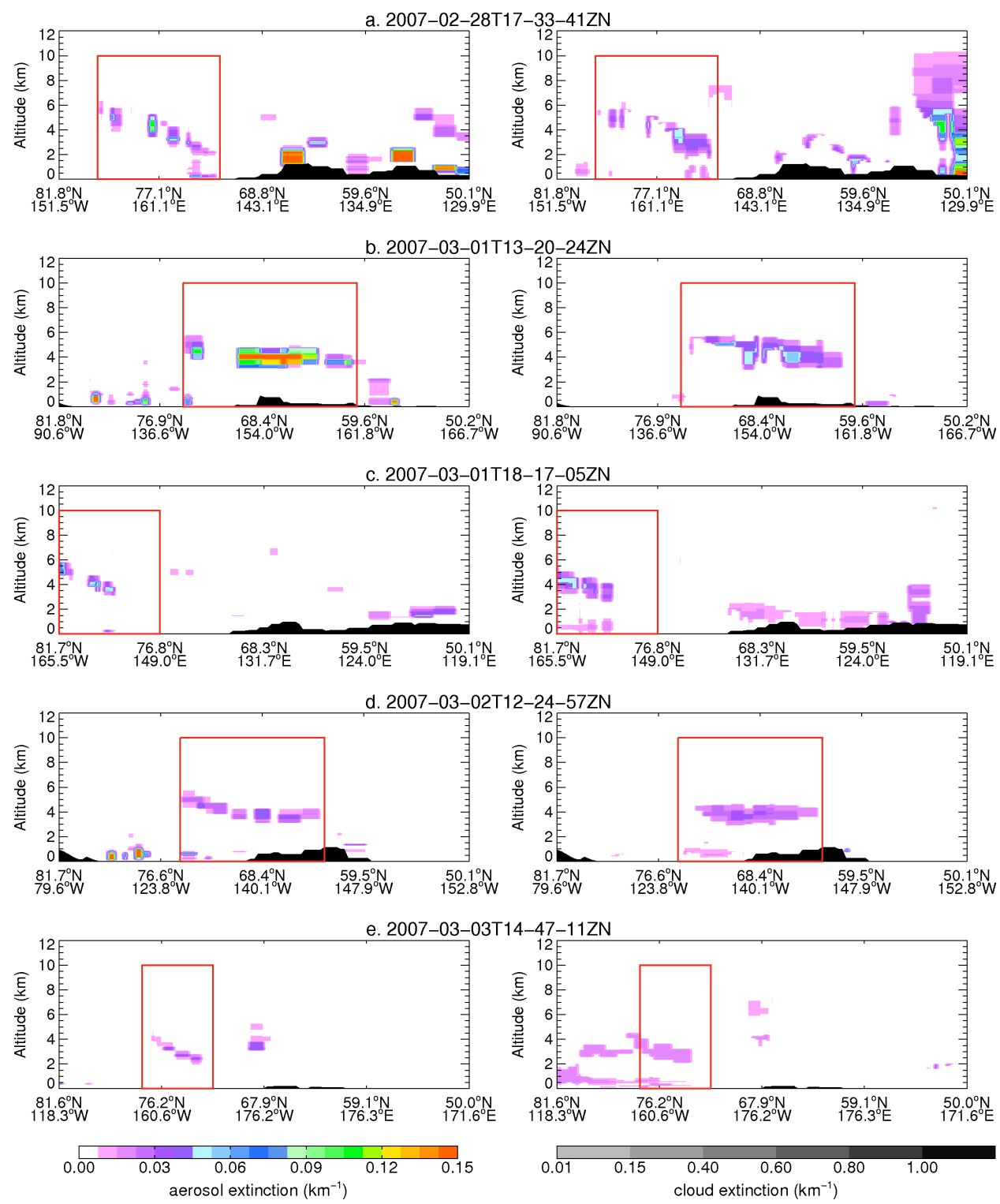

Fig. 4. Same as Fig. 2, but with the CALIOP extinction gridded onto the GEOS-Chem horizontal and vertical grid (left panels). The GEOSChem extinction cross sections (right panels) take into account the CALIOP altitude-dependent backscatter sensitivity threshold. In addition, model extinction is displayed only under cloud-free conditions for better comparison to CALIOP.

from the planetary boundary layer to the free troposphere. The $500 \mathrm{hPa}$ geopotential heights show that a deep trough extended over NW China. On 12 March at 12:00 UTC an elongated region of enhanced AOD separates from the cyclonic circulation and is quickly en route to the Arctic, driven by the strong zonal geopotential height gradient between the Siberian trough and the pronounced Omega blocking high in the North Pacific (H in Fig. 7, left panels).

Roughly half of all backtrajectories corresponding to the haze layers observed by CALIOP originated in the boundary layer. Of these $90 \%$ came from East Asia and $10 \%$ came from the Gobi desert (Fig. 6). Ascent took place entirely out- side the Arctic, predominantly during the early stages of the cyclone development on 10 and $11 \mathrm{March}$; it was very intense with parcel rising to $4-8 \mathrm{~km}$ and precipitation reaching $4 \mathrm{~mm} \mathrm{~h}^{-1}$ (not shown). We compare the GEOS-Chem AOD over the source region (Yellow Sea and Sea of Japan) and the Arctic, inferring an export efficiency of $\sim 10 \%$ for sulfate, $20 \%$ for BC, and $30-35 \%$ for dust. Compared to the previous case study, the sulfate export efficiency is lower $(10 \%$ vs. 20\%), likely due to the higher altitudes and thus more efficient scavenging encountered by these air parcels (Fig. 6). 
Table 2. Summary of the 37 Arctic aerosol layers observed by CALIOP during the 12-19 March export event. Refer to Table 1 for the legend.

\begin{tabular}{|c|c|c|c|c|c|c|c|c|}
\hline \multirow[b]{2}{*}{ Date } & \multirow{2}{*}{\multicolumn{2}{|c|}{$\begin{array}{l}\text { Location of endpoints } \\
\text { (Latitude; Longitude) }\end{array}$}} & \multicolumn{5}{|c|}{ CALIOP } & \multirow{2}{*}{$\begin{array}{c}\text { GEOS-Chem } \\
\text { Int. } \beta^{\prime \mathrm{a}} \\
\left(\times 10^{-3} \mathrm{sr}^{-1}\right)\end{array}$} \\
\hline & & & $\begin{array}{r}\text { Length } \\
(\mathrm{km})\end{array}$ & $\begin{array}{c}\text { Mean } \\
\text { Altitude }(\mathrm{km})\end{array}$ & IVDR & $\begin{array}{l}\text { Color } \\
\text { Ratio }\end{array}$ & $\begin{array}{c}\text { Int. } \beta^{\prime \mathrm{a}} \\
\left(\times 10^{-3} \mathrm{sr}^{-1}\right)\end{array}$ & \\
\hline $03-1217.59 \mathrm{~N}$ & $64.5^{\circ} \mathrm{N} ; 132.3^{\circ} \mathrm{E}$ & $71.1^{\circ} \mathrm{N} ; 140.1^{\circ} \mathrm{E}$ & 800 & 4.6 & 0.063 & 0.29 & - & - \\
\hline $03-1318.43 \mathrm{~N}$ & $66.8^{\circ} \mathrm{N} ; 123.7^{\circ} \mathrm{E}$ & $77.4^{\circ} \mathrm{N} ; 145.1^{\circ} \mathrm{E}$ & 1360 & 4.0 & 0.054 & 0.30 & - & - \\
\hline 03-14 00.26 D & $76.6^{\circ} \mathrm{N} ; 150.6^{\circ} \mathrm{E}$ & $80.5^{\circ} \mathrm{N} ; 128.4^{\circ} \mathrm{E}$ & 640 & 4.1 & 0.058 & 0.31 & 1.03 & 0.70 \\
\hline $03-1402.05 \mathrm{D}$ & $69.1^{\circ} \mathrm{N} ; 141.4^{\circ} \mathrm{E}$ & $77.7^{\circ} \mathrm{N} ; 121.7^{\circ} \mathrm{E}$ & 1120 & 3.2 & 0.069 & 0.36 & 1.81 & 0.94 \\
\hline 03-14 18.34 D & $79.8^{\circ} \mathrm{N} ; 147.2^{\circ} \mathrm{E}$ & $81.3^{\circ} \mathrm{N} ; 164.6^{\circ} \mathrm{E}$ & 355 & 3.9 & 0.062 & 0.32 & 1.77 & 1.20 \\
\hline $03-1419.26 \mathrm{~N}$ & $74.2^{\circ} \mathrm{N} ; 124.3^{\circ} \mathrm{E}$ & $79.6^{\circ} \mathrm{N} ; 146.0^{\circ} \mathrm{E}$ & 800 & 4.3 & 0.053 & 0.25 & - & - \\
\hline 03-14 20.13 D & $79.8^{\circ} \mathrm{N} ; 122.6^{\circ} \mathrm{E}$ & $81.8^{\circ} \mathrm{N} ; 167.3^{\circ} \mathrm{E}$ & 795 & 3.0 & 0.053 & 0.40 & - & - \\
\hline 03-14 21.52 D & $79.5^{\circ} \mathrm{N} ; 175.5^{\circ} \mathrm{E}$ & $81.6^{\circ} \mathrm{N} ; 121.8^{\circ} \mathrm{E}$ & 960 & 3.4 & 0.054 & 0.34 & - & - \\
\hline $03-1423.30 \mathrm{D}$ & $78.0^{\circ} \mathrm{N} ; 159.0^{\circ} \mathrm{E}$ & $81.7^{\circ} \mathrm{N} ; 121.2^{\circ} \mathrm{E}$ & 820 & 3.2 & 0.077 & 0.41 & - & - \\
\hline 03-15 01.09 D & $76.9^{\circ} \mathrm{N} ; 138.5^{\circ} \mathrm{E}$ & $81.3^{\circ} \mathrm{N} ; 106.6^{\circ} \mathrm{E}$ & 800 & 3.9 & 0.069 & 0.30 & - & - \\
\hline 03-15 17.38 D & $79.5^{\circ} \mathrm{N} ; 159.4^{\circ} \mathrm{E}$ & $80.5^{\circ} \mathrm{N} ; 129.6^{\circ} \mathrm{W}$ & 1275 & 4.0 & 0.049 & 0.27 & 0.98 & 0.91 \\
\hline $03-15$ 19.17 D & $80.8^{\circ} \mathrm{N} ; 146.2^{\circ} \mathrm{E}$ & $81.4^{\circ} \mathrm{N} ; 167.5^{\circ} \mathrm{W}$ & 770 & 3.7 & 0.063 & 0.34 & 1.57 & 0.86 \\
\hline $03-1520.56 \mathrm{D}$ & $80.9^{\circ} \mathrm{N} ; 176.7^{\circ} \mathrm{E}$ & $81.8^{\circ} \mathrm{N} ; 148.1^{\circ} \mathrm{E}$ & 480 & 3.4 & 0.072 & 0.31 & - & - \\
\hline $03-1601.53 \mathrm{D}$ & $81.2^{\circ} \mathrm{N} ; 97.7^{\circ} \mathrm{E}$ & $81.7^{\circ} \mathrm{N} ; 63.2^{\circ} \mathrm{E}$ & 560 & 3.2 & 0.048 & 0.29 & 0.51 & 0.32 \\
\hline 03-16 11.46 D & $79.3^{\circ} \mathrm{N} ; 113.9^{\circ} \mathrm{W}$ & $81.2^{\circ} \mathrm{N} ; 95.6^{\circ} \mathrm{W}$ & 395 & 4.7 & 0.065 & 0.29 & - & - \\
\hline $03-1612.39 \mathrm{~N}$ & $72.9^{\circ} \mathrm{N} ; 136.4^{\circ} \mathrm{W}$ & $79.1^{\circ} \mathrm{N} ; 115.2^{\circ} \mathrm{W}$ & 880 & 3.7 & 0.047 & 0.21 & 0.44 & 0.83 \\
\hline $03-16$ 13.25 D & $79.3^{\circ} \mathrm{N} ; 139.0^{\circ} \mathrm{W}$ & $81.8^{\circ} \mathrm{N} ; 93.9^{\circ} \mathrm{W}$ & 835 & 2.7 & 0.051 & 0.41 & - & - \\
\hline $03-1614.17 \mathrm{~N}$ & $76.3^{\circ} \mathrm{N} ; 152.6^{\circ} \mathrm{W}$ & $79.1^{\circ} \mathrm{N} ; 140.3^{\circ} \mathrm{W}$ & 420 & 3.2 & 0.047 & 0.24 & - & - \\
\hline 03-16 15.04 D & $79.3^{\circ} \mathrm{N} ; 163.6^{\circ} \mathrm{W}$ & $81.8^{\circ} \mathrm{N} ; 116.0^{\circ} \mathrm{W}$ & 875 & 3.6 & 0.061 & 0.35 & - & - \\
\hline $03-1616.43$ D & $80.7^{\circ} \mathrm{N} ; 118.0^{\circ} \mathrm{W}$ & $81.3^{\circ} \mathrm{N} ; 167.0^{\circ} \mathrm{W}$ & 820 & 4.4 & 0.064 & 0.34 & 2.14 & 0.98 \\
\hline $03-16$ 18.22 D & $75.2^{\circ} \mathrm{N} ; 114.2^{\circ} \mathrm{W}$ & $81.8^{\circ} \mathrm{N} ; 165.6^{\circ} \mathrm{W}$ & 1270 & 4.1 & 0.073 & 0.30 & 2.32 & 1.10 \\
\hline $03-1620.01 \mathrm{D}$ & $76.4^{\circ} \mathrm{N} ; 142.3^{\circ} \mathrm{W}$ & $80.4^{\circ} \mathrm{N} ; 163.9^{\circ} \mathrm{W}$ & 640 & 4.1 & 0.081 & 0.31 & 1.15 & 0.74 \\
\hline $03-1711.43 \mathrm{~N}$ & $67.2^{\circ} \mathrm{N} ; 130.7^{\circ} \mathrm{W}$ & $76.3^{\circ} \mathrm{N} ; 114.0^{\circ} \mathrm{W}$ & 1140 & 3.2 & 0.063 & 0.26 & 1.66 & 0.79 \\
\hline 03-17 12.29 D & $79.0^{\circ} \mathrm{N} ; 126.8^{\circ} \mathrm{W}$ & $80.7^{\circ} \mathrm{N} ; 113.5^{\circ} \mathrm{W}$ & 315 & 3.9 & 0.052 & 0.27 & - & - \\
\hline $03-1713.22 \mathrm{~N}$ & $69.2^{\circ} \mathrm{N} ; 153.0^{\circ} \mathrm{W}$ & $78.8^{\circ} \mathrm{N} ; 127.8^{\circ} \mathrm{W}$ & 1280 & 3.7 & 0.046 & 0.22 & 0.83 & 0.68 \\
\hline 03-17 14.08 D & $79.0^{\circ} \mathrm{N} ; 151.5^{\circ} \mathrm{W}$ & $81.8^{\circ} \mathrm{N} ; 115.3^{\circ} \mathrm{W}$ & 715 & 3.8 & 0.053 & 0.26 & - & - \\
\hline $03-17$ 15.47 D & $81.6^{\circ} \mathrm{N} ; 119.7^{\circ} \mathrm{W}$ & $81.8^{\circ} \mathrm{N} ; 139.9^{\circ} \mathrm{W}$ & 320 & 3.8 & 0.065 & 0.33 & - & - \\
\hline 03-17 17.26 D & $78.8^{\circ} \mathrm{N} ; 114.2^{\circ} \mathrm{W}$ & $81.4^{\circ} \mathrm{N} ; 140.2^{\circ} \mathrm{W}$ & 560 & 3.8 & 0.067 & 0.28 & - & - \\
\hline 03-17 19.05 D & $71.7^{\circ} \mathrm{N} ; 117.4^{\circ} \mathrm{W}$ & $77.3^{\circ} \mathrm{N} ; 131.6^{\circ} \mathrm{W}$ & 740 & 3.1 & 0.079 & 0.28 & 0.37 & 0.30 \\
\hline 03-17 20.44 D & $66.6^{\circ} \mathrm{N} ; 135.4^{\circ} \mathrm{W}$ & $75.0^{\circ} \mathrm{N} ; 149.1^{\circ} \mathrm{W}$ & 1040 & 3.2 & 0.079 & 0.34 & 1.31 & 0.66 \\
\hline $03-1812.26 \mathrm{~N}$ & $65.5^{\circ} \mathrm{N} ; 143.3^{\circ} \mathrm{W}$ & $74.1^{\circ} \mathrm{N} ; 130.7^{\circ} \mathrm{W}$ & 1060 & 3.3 & 0.044 & 0.21 & 1.86 & 0.92 \\
\hline $03-1814.05 \mathrm{~N}$ & $65.5^{\circ} \mathrm{N} ; 168.0^{\circ} \mathrm{W}$ & $74.6^{\circ} \mathrm{N} ; 154.4^{\circ} \mathrm{W}$ & 1115 & 2.5 & 0.052 & 0.26 & 0.47 & 0.45 \\
\hline 03-18 19.48 D & $69.0^{\circ} \mathrm{N} ; 124.6^{\circ} \mathrm{W}$ & $74.8^{\circ} \mathrm{N} ; 134.5^{\circ} \mathrm{W}$ & 720 & 3.1 & 0.096 & 0.32 & 1.13 & 0.52 \\
\hline $03-1911.31 \mathrm{~N}$ & $66.4^{\circ} \mathrm{N} ; 128.5^{\circ} \mathrm{W}$ & $69.1^{\circ} \mathrm{N} ; 125.4^{\circ} \mathrm{W}$ & 320 & 3.3 & 0.045 & 0.22 & 0.60 & 0.55 \\
\hline $03-1911.31 \mathrm{~N}$ & $72.9^{\circ} \mathrm{N} ; 119.3^{\circ} \mathrm{W}$ & $76.3^{\circ} \mathrm{N} ; 110.9^{\circ} \mathrm{W}$ & 440 & 2.4 & 0.033 & 0.18 & - & - \\
\hline 03-19 $13.10 \mathrm{~N}$ & $70.2^{\circ} \mathrm{N} ; 148.6^{\circ} \mathrm{W}$ & $76.1^{\circ} \mathrm{N} ; 136.1^{\circ} \mathrm{W}$ & 760 & 3.4 & 0.045 & 0.24 & - & - \\
\hline 03-19 20.32 D & $68.1^{\circ} \mathrm{N} ; 134.0^{\circ} \mathrm{W}$ & $73.3^{\circ} \mathrm{N} ; 142.0^{\circ} \mathrm{W}$ & 640 & 2.2 & 0.097 & 0.30 & 1.03 & 0.43 \\
\hline Mean $^{\mathrm{b}}$ & - & - & 780 & 3.5 & $\begin{array}{c}0.061 \pm 0.014 \\
\mathrm{~N}: 0.051 \pm 0.008 \\
\mathrm{D}: 0.067 \pm 0.041\end{array}$ & $\begin{array}{c}0.30 \pm 0.05 \\
\mathrm{~N}: 0.25 \pm 0.03 \\
\mathrm{D}: 0.32 \pm 0.04\end{array}$ & $\begin{array}{c}- \\
1.21 \pm 0.60 \\
-\end{array}$ & $0.73 \pm 0.25$ \\
\hline
\end{tabular}

${ }^{a}$ Mean attenuated particle backscatter $\left(\beta^{\prime}\right)$ integrated in the plume. $\beta^{\prime}$ is given only for cases with clear sky conditions persisting over at least $320 \mathrm{~km}$.

$\mathrm{b}$ IVDR and color ratio are weighted by the length of the cross-section.

Once the plume reached the Arctic, slow subsidence started at a rate of $0.6 \mathrm{~cm} \mathrm{~s}^{-1}$. Parcel potential temperature decreased by $1.5-2^{\circ} \mathrm{C}$ ay $^{-1}$ as a results of radiative cooling and, possibly, turbulent mixing with the surrounding air.

\subsubsection{Missclassification of aerosols as clouds}

In this case, the haze layers with a high dust component are classified as clouds instead of aerosols in the CALIOP level 2 daytime products (Fig. 8, panel a, b, d), but are correctly classified as aerosols in the nighttime retrievals (panels c, e). We believe that this erroneous classification is caused by assumptions in the cloud/aerosol discrimination algorithm at high latitudes. Indeed, a feature is initially classified by the algorithm as cloud or aerosol based on the intensity of attenuated backscatter, color ratio and altitude (Liu et al., 2004). Then, aerosol layers with an IVDR value in excess of a given threshold are reclassified as clouds and denominated "CAD 101" (Liu et al., 2009). The IDVR threshold is latitude-dependent: $0.15\left(50-60^{\circ} \mathrm{N}\right), 0.10\left(60-70^{\circ} \mathrm{N}\right), 0.05$ $\left(70-82^{\circ} \mathrm{N}\right)$. The procedure was implemented to reduce misclassification of cirrus clouds and ice-crystal precipitation as aerosols (Liu et al., 2009). This type of precipitation, also called diamond dust when it occurs under clear-sky conditions, has optical properties very similar to those of dust (Bourdages et al., 2009). On 12-17 March, the IVDR of 

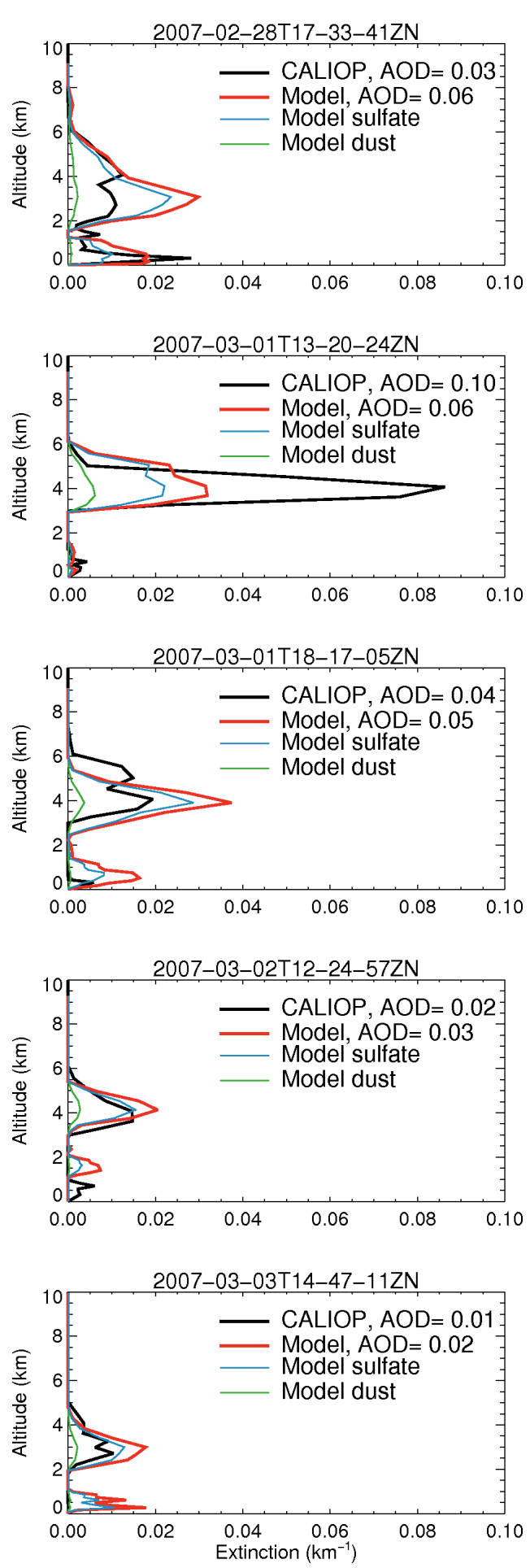

Fig. 5. CALIOP (black) and GEOS-Chem (red) mean aerosol extinction profiles for the cloud-free regions within the red boxes in Fig. 4. The CALIOP sensitivity threshold is applied to the modeled extinction profiles. The CALIOP extinction is gridded onto the GEOS-Chem vertical grid. The green and blue lines represent the extinction attributed to dust and sulfate respectively. The modeled and observed AOD, calculated by integration of the extinction profile over the vertical extent of each plume are listed on each panel.
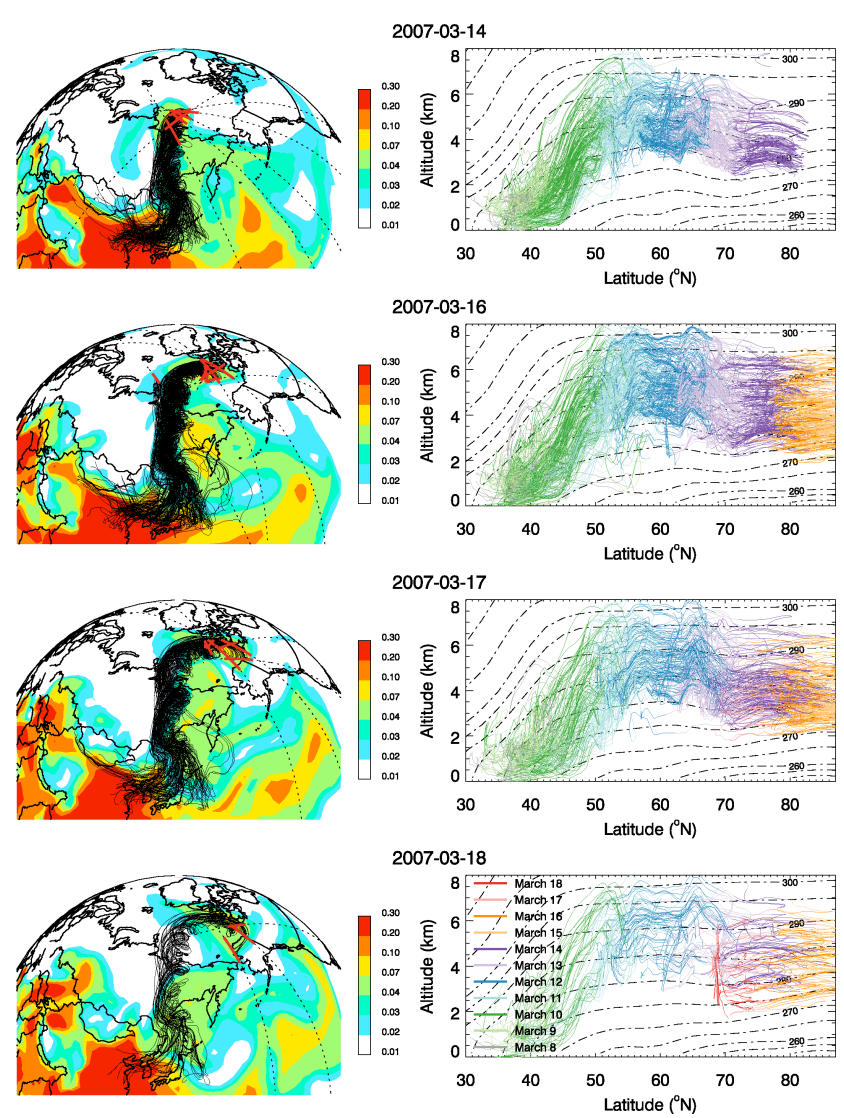

Fig. 6. Same as Fig. 1 but for 14-18 March 2007. The potential temperature contours (right panels) are zonally and temporally averaged in the longitude interval $\left(110^{\circ} \mathrm{E}, 160^{\circ} \mathrm{W}\right)$ from $9 \mathrm{March}, 0 \mathrm{Z}$ until the time when the last plume was observed, for each day.

aerosol layers observed by CALIOP range from 0.03 to 0.09 (Table 2), values which are common for winter/spring Arctic aerosols (Ishii et al., 2001). As IDVR often exceeds the 0.05 threshold, aerosol layers poleward of $70^{\circ} \mathrm{N}$ are misclassified as cloud CAD 101. Thus, the same coherent aerosol feature is classified as either aerosol or cloud solely depending on its latitude (Fig. 8, panel e). The misclassification is more frequent under daytime conditions (69\% of the layers are missclassified) compared to nighttime conditions (32\% of the layers are misclassified). The CAD 101 backtrajectories follow very closely the backtrajectories associated with correctly classified layers. Observations from the CloudSat satellite for the CAD 101 layers do not indicate any condensed water phase, further confirming the misclassification (not shown).

The most recent version of the CALIOP algorithm, v3.01, does not use the CAD 101 classification anymore, but instead incorporates latitude and depolarization ratio into a five dimensional probability density function (Liu et al., 2010). Relative to v2.01, fewer misclassifications occur under nighttime conditions for this case study. However, daytime misclassification of aerosol layers as clouds persists. 

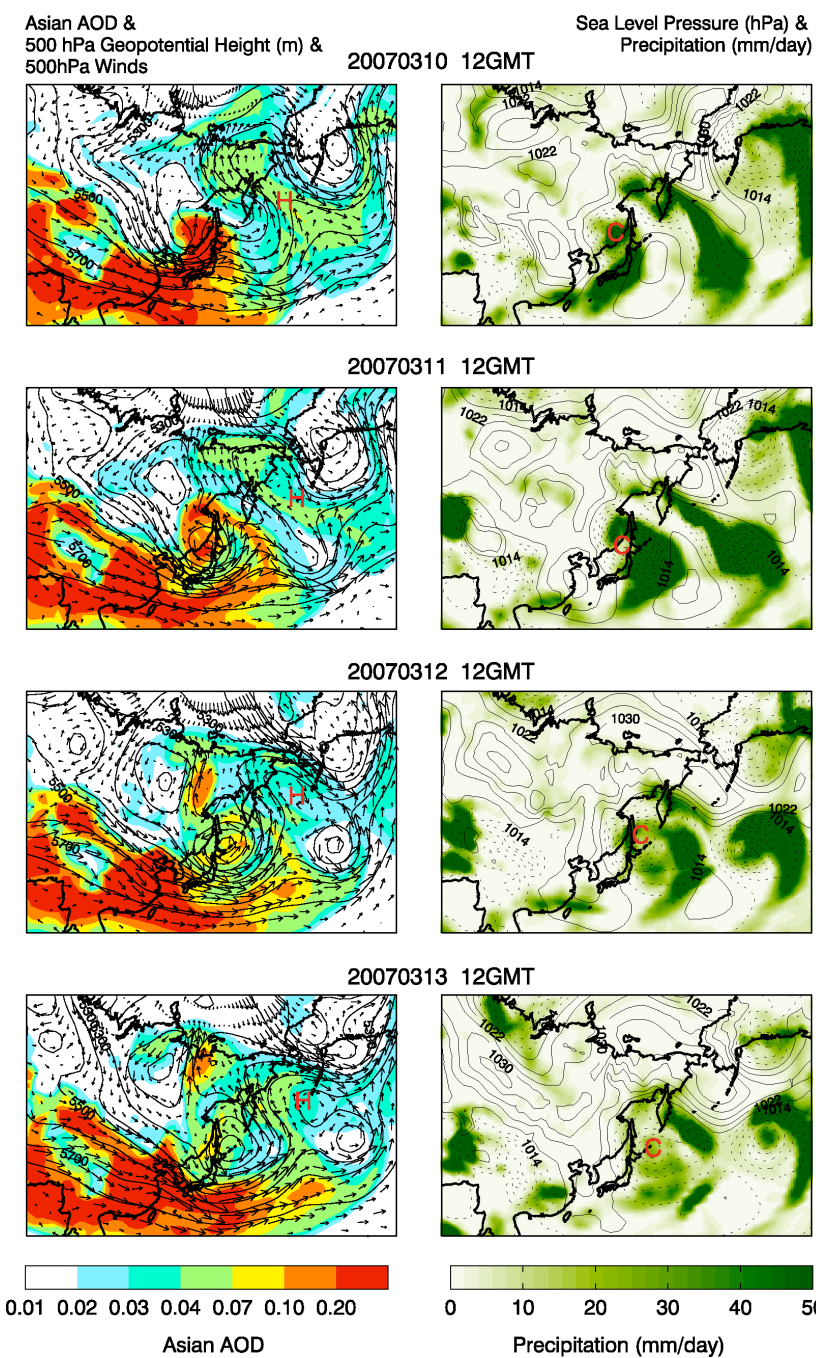

20070313 12GMT

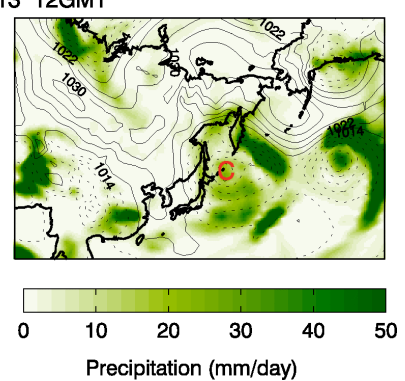

Fig. 7. Synoptic situation during the initial stages of the export event of 12-19 March 2007. Conventions are the same as in Fig. 3.

\subsubsection{Comparison between observed and modeled haze layers}

There is good agreement between GEOS-Chem and CALIOP on the horizontal and vertical location of the plumes (Figs. 6 and 8). The model shows that dust accounts for $20 \%$ of the AOD of this haze event. This is somewhat lower than expected based on the high IDVR observed by CALIPSO. We attribute this to a model underestimate of dust emissions during this event. Indeed, when compared to MODIS AOD observations over the Sea of Japan, where the dust/pollution mixture had accumulated at the onset of the transport event, GEOS-Chem is a factor of 2 too low.

Though we can compute GEOS-Chem mean plume AOD (0.052) we can not directly compare it to CALIOP because of the misclassification. Instead, we compare attenuated backscatter from the Level-1 profile data. We select all cloud free regions of the plumes $(>320 \mathrm{~km})$ listed in Table 2. We then average the attenuated backscatter profiles horizontally and smooth them with a running mean. We subtract the molecular attenuated backscatter from the measured attenuated profile, to obtain the particulate attenuated backscatter profile assuming a lidar ratio of $50 \mathrm{sr}$ (Vaughan et al., 2004). In order to convert modeled extinction profiles into backscatter profiles we use the following lidar ratios: $70 \mathrm{sr}$ for sulfate, BC, and organic carbon; 40 sr for dust; and 20 sr for sea salt (Winker et al., 2009). The extinction threshold is not applied in this case because we horizontally average the backscatter over a large domain, thus enhancing the signal-to-noise ratio.

The resulting attenuated aerosol backscatter $\left(\beta^{\prime}\right)$, integrated over the altitude interval where CALIOP observes the plume, are $1.21 \pm 0.60$ for CALIOP and $0.73 \pm 0.25$ for GEOS-Chem (Table 2). The model $\beta^{\prime}$ is lower than observations by $\sim 40 \%$, which is consistent with a model underestimate of the amount of dust in the plume.

\section{$3.3 \quad 20-27$ October export episode}

This last episode occurred in mid-autumn, a time that is not typically associated with elevated Arctic Haze levels. This is the time of the year when the Siberian anticyclone begins to build up at the end of the Monsoon season.

\subsubsection{Morphology and optical properties of the observed haze layers}

Figure 9 shows the location of the observed layers and their associated backtrajectories. The first plume cross section was observed above the northeastern Siberian sector of the Arctic. Part of the plume then traveled across the Arctic Ocean and it was last observed by CALIOP on 27 October, near the Canadian islands of the Northwest Territories. The aerosol layers have a mean thickness of $1 \mathrm{~km}$, and are initially observed at $3-5 \mathrm{~km}$ altitude, subsiding to $2-3.5 \mathrm{~km}$ after $25 \mathrm{Oc}-$ tober (Table S1). Values of IVDR and color ratio are very similar to those of the February case study, indicating pollution aerosols and low dust levels.

\subsubsection{Meteorology}

Figure 10 illustrates the synoptic situation during the export event. The ascent is associated with the early development of a mid-latitude cyclone triggered by a deep trough in the middle troposphere. A low-pressure center is seen at the surface on 17 October 2007 in the lee of the Yablonovyy mountain range, near the border between northeastern China and Russia ( $\mathrm{L}$ in Fig. 10, right panels). The build-up of the polluted airmass in the source area was favored by weak surface winds and anticyclonic conditions during the preceding two days. The aerosols were lifted up to the free troposphere and were carried northward along the downstream ridge. The backtrajectories (Fig. 9) indicate that the aerosols originated in NE China, with $4 \%$ of trajectories coming from the Gobi desert. 

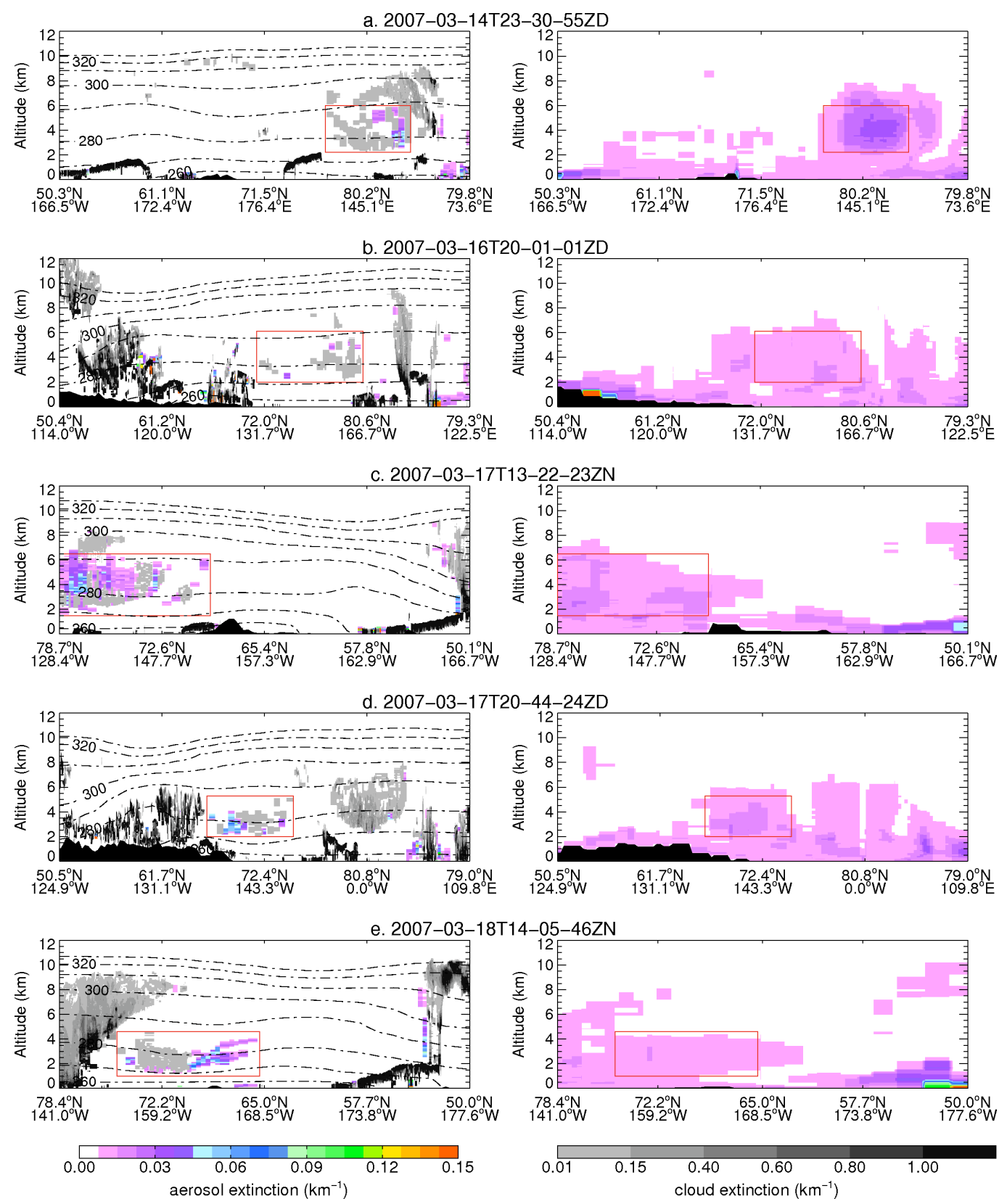

Fig. 8. Same as Fig. 2 for a subset of five major plume cross sections for the 12-19 March 2007 event. The red box delimits the aerosol plume cross sections, which are sometimes misclassified as clouds (see text).

Precipitation occurred during most of the transport; $50 \%$ of the precipitable water fell in the first 3 days (16-18 October), and $30-40 \%$ in the following four days (19-22 October), continuing more sporadically until 25 October. For this event, we find export efficiencies of $13 \%$ for sulfate, $10 \%$ for BC, and 25-40\% for dust in GEOS-Chem. These low export efficiencies for sulfate and $\mathrm{BC}$ are consistent with prolonged precipitation.

After 25 October, the plume began to subside, following the spatially inhomogeneous pattern of low and high pressure systems over the Arctic. Backtrajectories indicate a steady cooling in potential temperature of $\sim 1.5^{\circ} \mathrm{Cday}^{-1}$, similar to the cooling rate recorded for the springtime export events.

\subsubsection{Comparison between observed and modeled haze layers}

Figure 11 shows five plume cross sections observed during this event. Ice clouds are often observed within the aerosol enhancement (panels c, d, e in Fig. 11). The model generally 

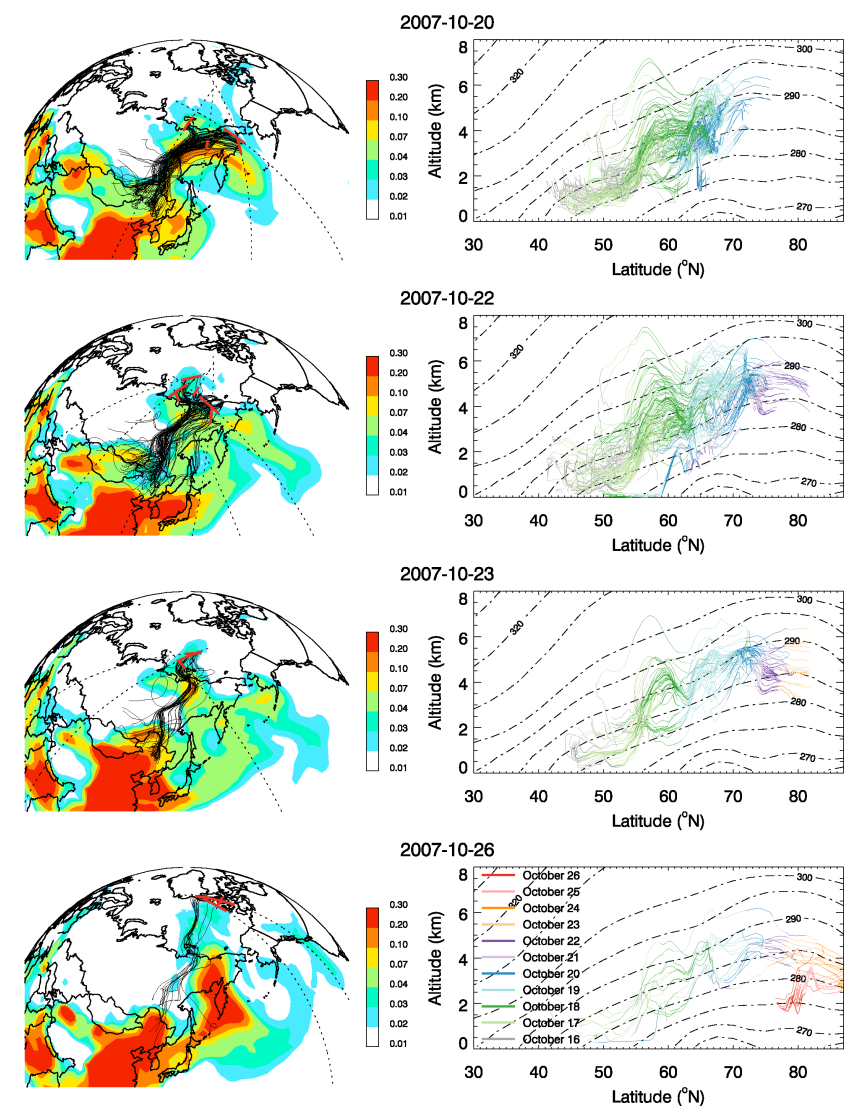

Fig. 9. Same as Fig. 1, but for the 20-27 October 2007 event. The potential temperature contours are zonally and temporally averaged in the longitude interval $\left(100^{\circ} \mathrm{E}, 180^{\circ} \mathrm{E}\right)$ from 17 October , $0 \mathrm{Z}$ until the time when the last plume was observed, for each day.

reproduces the location of the aerosol layers throughout the 10-day duration of the event. Even 9-10 days after the export began, the model is able to reproduce the thin aerosol layers in the Beaufort Sea, although the magnitude of the subsidence undergone by the plume seems to be underestimated (Fig. 11, panels $d$ and e). GEOS-Chem underestimates the observed extinction in the plumes (model $\mathrm{AOD}=0.022$, observed AOD $=0.04$, Table S1). For the column AOD, we restrict our comparison to the $2-10 \mathrm{~km}$ altitude range because of extensive low level cloud cover. The resulting modeled 2$10 \mathrm{~km}$ AOD is 0.042 , which compares well to the CALIOP column AOD of 0.04. However, if we apply the CALIOP sensitivity threshold to the model, the $2-10 \mathrm{~km}$ AOD decreases to 0.002 as the model values are often below the sensitivity threshold of CALIOP (Table S1). This is likely to be due to numerical mixing leading to excessive dilution over the course of this transport event. Indeed, Rastigejev et al. (2010) demonstrated that CTMs tend to dilute pollution plumes as a result of numerical diffusion and stretching of the plume in complex geophysical flow.
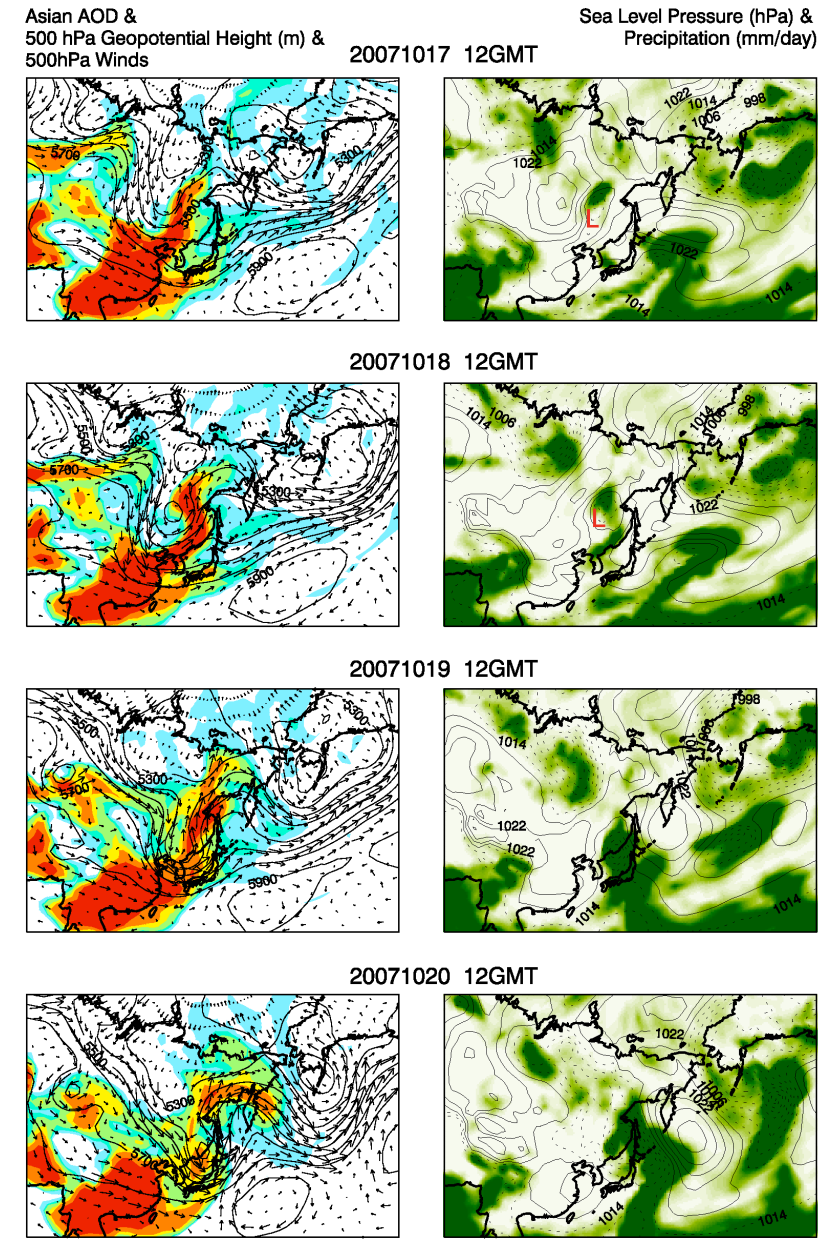

$0.010 .020 .03 \quad 0.04 \quad 0.07 \quad 0.10 \quad 0.20$

Asian AOD

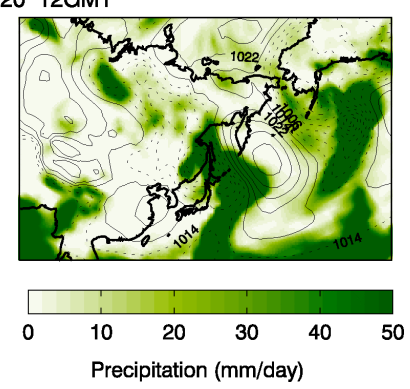

Fig. 10. Synoptic situation during the initial stages of the export event of 20-27 October 2007. Conventions are the same as in Fig. 3.

\section{Discussion}

In all three export events documented here, the initial phase of the transport was strongly meridional, confined between $120^{\circ} \mathrm{E}-180^{\circ} \mathrm{E}$, with a weak or absent zonal component. Transport was rapid (3-4 days to reach the Arctic) and took place at 3-7 km altitude. These characteristics are consistent with the rapid transport pathway from East Asia described by Stohl (2006). Once in the Arctic, plumes generally travel slowly, and often migrate toward the northeast. In GEOSChem, the dominant aerosol component in the plumes is sulfate in all cases, representing $80 \%$ of the extinction. Dust accounts for $15-18 \%$ of the extinction, and $\mathrm{BC}$ for the rest. This is consistent with the CALIOP classification of the observed aerosols layers, with $75 \%$ being "clean continental", $15 \%$ "polluted continental", and the remaining $10 \%$ as "polluted dust" and "smoke". 

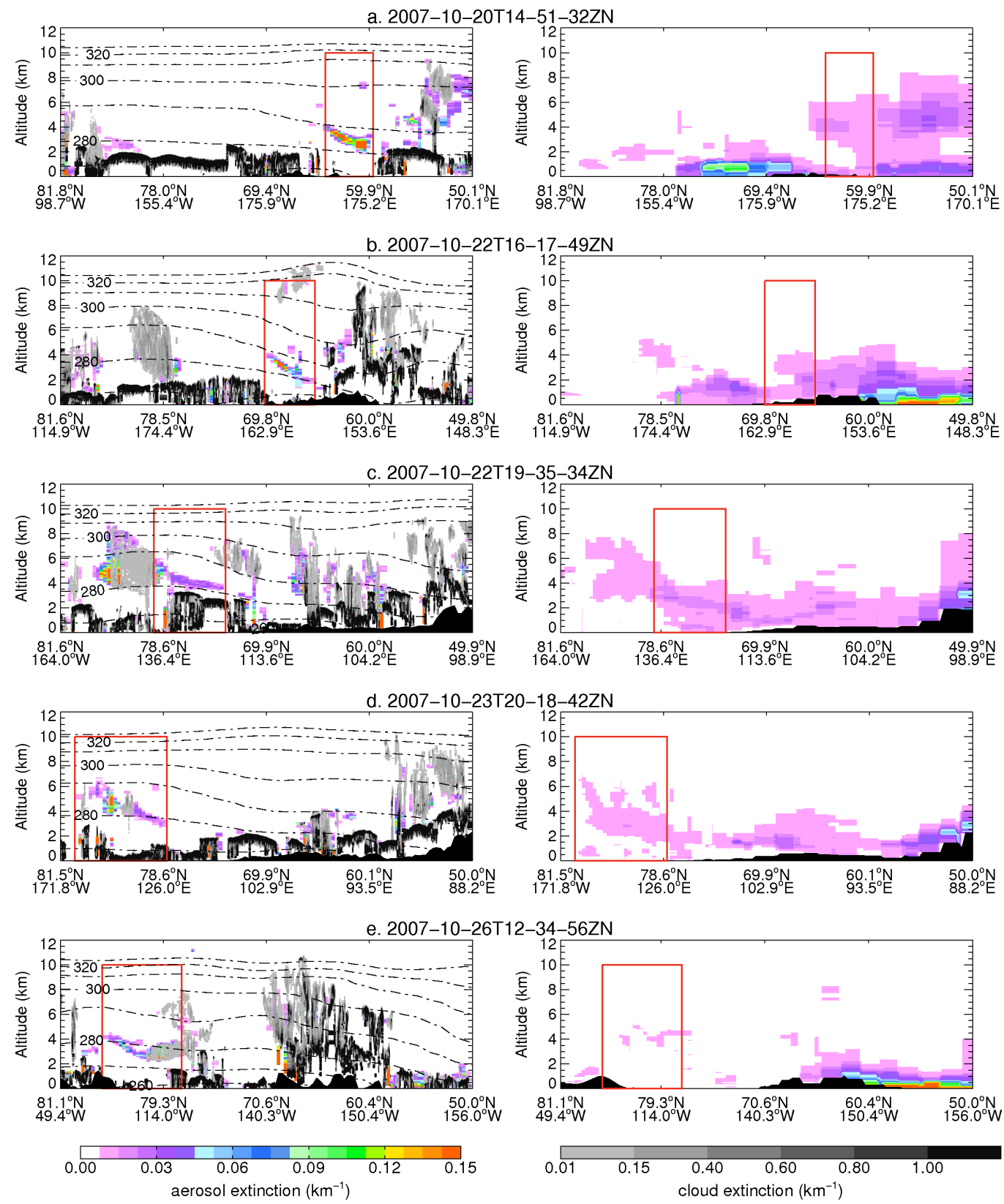

Fig. 11. Same as Fig. 2, for a subset of five major plume cross sections for the 20-27 October 2007 event.

Intense precipitation took place in the initial phase of export for the two springtime cases. For the autumn case, precipitation occurred weakly during most of the transport to the Arctic. As a result of these wet processes, we derived export efficiencies of $10-20 \%$ for sulfate, $10-20 \%$ for BC, and 30$40 \%$ for dust in GEOS-Chem. These values are consistent with the study of Park et al. (2005), who used aircraft observations in Asian outflow to derive an export efficiency at $4-6 \mathrm{~km}$ altitude of $6-21 \%$ for $\mathrm{SO}_{\mathrm{x}}\left(\mathrm{SO}_{4}^{2-}+\mathrm{SO}_{2}\right)$ and $27-$ $38 \%$ for BC. Sulfate is scavenged most efficiently during the initial strong uplift, while more BC survives this early phase when it is hydrophobic. Following Park et al. (2005), we assume a 1-day conversion timescale from fresh hydrophobic $\mathrm{BC}$ conversion to hydrophilic $\mathrm{BC}$. Relative to sulfate and $\mathrm{BC}$, dust displays the least scavenging as it is emitted at higher altitudes and latitudes in deserts of the Gobi, Takla Makan, and inner Mongolia regions (Shao and Deng, 2006).

Our case studies illustrate that in order for an Asian airmass to travel to the Arctic two conditions must be satisfied: (1) a lifting mechanism has to be present and, (2) a favorable synoptic pattern leading to meridional transport must persist for at least 3-7 days. Here, the lifting mechanism 
Table 3. Sign of the WP and PNA indices during the early stages of the nine major events observed by CALIOP during the period 2007-2009.

\begin{tabular}{lccc}
\hline Date $^{\mathrm{a}}$ & $\mathrm{WP}^{\mathrm{b}}$ & PNA $^{\mathrm{b}}$ & AME $^{\mathrm{b}}$ \\
\hline 28 Feb-4 Mar 2007 & - & - & ++ \\
12 Mar-19 Mar 2007 & - & $\sim 0$ & ++ \\
20 Oct-27 Oct 2007 & $\sim 0$ & + & + \\
12 Mar-13 Mar 2007 & $\sim 0$ & + & + \\
14 Mar-17 Mar 2008 & + & $\sim 0$ & ++ \\
20 Mar-22 Mar 2008 & - & - & ++ \\
03 Dec-07 Dec 2008 & - & + & ++ \\
15 Dec-18 Dec 2008 & + & $\sim 0$ & ++ \\
22 Dec-25 Dec 2008 & + & - & ++ \\
14 Mar-16 Mar 2009 & $\sim 0$ & - & ++ \\
20 Mar-27 Mar 2009 & - & $\sim 0$ & ++ \\
\hline
\end{tabular}

a The dates correspond to the times when Arctic haze events are observed by CALIOP. ${ }^{\mathrm{b}}$ A double sign indicates absolute values of the index greater than two standard deviations during the 3-day initial phase of export. Near zero values are those whose absolute values within \pm 0.5 standard deviations.

was associated with a low-pressure center accompanying the genesis or decay of a mid-latitude cyclone. Late winter and spring are the most active cyclogenesis periods in East Asia. NE China, with storm tracks originating in the lee of the Altai-Sayan mountains and along the East Asian coastline (Chen et al., 1991). In addition, meridional transport from Asia maximizes in winter/spring because of the frequent occurrence of blocking patterns in the $120^{\circ} \mathrm{E}-150^{\circ} \mathrm{E}$ longitude band (Barriopedro et al., 2006).

Figure 12 illustrates the $500 \mathrm{hPa}$ geopotential height anomalies (left panels) and sea level pressure anomalies (right panels) corresponding to the first three days of transport for each case study examined here. In all three cases a positive anomaly in geopotential height and sea level pressure is located in the NW Pacific, accompanied by a negative anomaly over Eastern Siberia or Northern China. The anomaly pattern for the two spring case studies shows a clear blocking configuration. The October case study displays a trough-ridge configuration. By inspection of the CALIOP 2008 and 2009 observations, we identified eight additional Asian export events (Table 3). These events display similar $500 \mathrm{hPa}$ geopotential height anomalies, with either a blocking pattern or a trough-ridge configuration favoring poleward transport. By compositing all 11 events, we find a clear eastwest dipole pattern in the anomalies (Fig. 12, bottom panel).

Now, we examine how these anomaly patterns relate to atmospheric teleconnection indices, in particular the Western Pacific (WP) and the Pacific North American (PNA) indices, which are leading modes of low-frequency variability over the North Pacific (Wallace and Gutzler, 1981). Table 3 summarizes the sign of the WP and PNA indices during the initial stage of export for the eleven major episodes observed by CALIOP in 2007-2009. The WP index is negative in 5

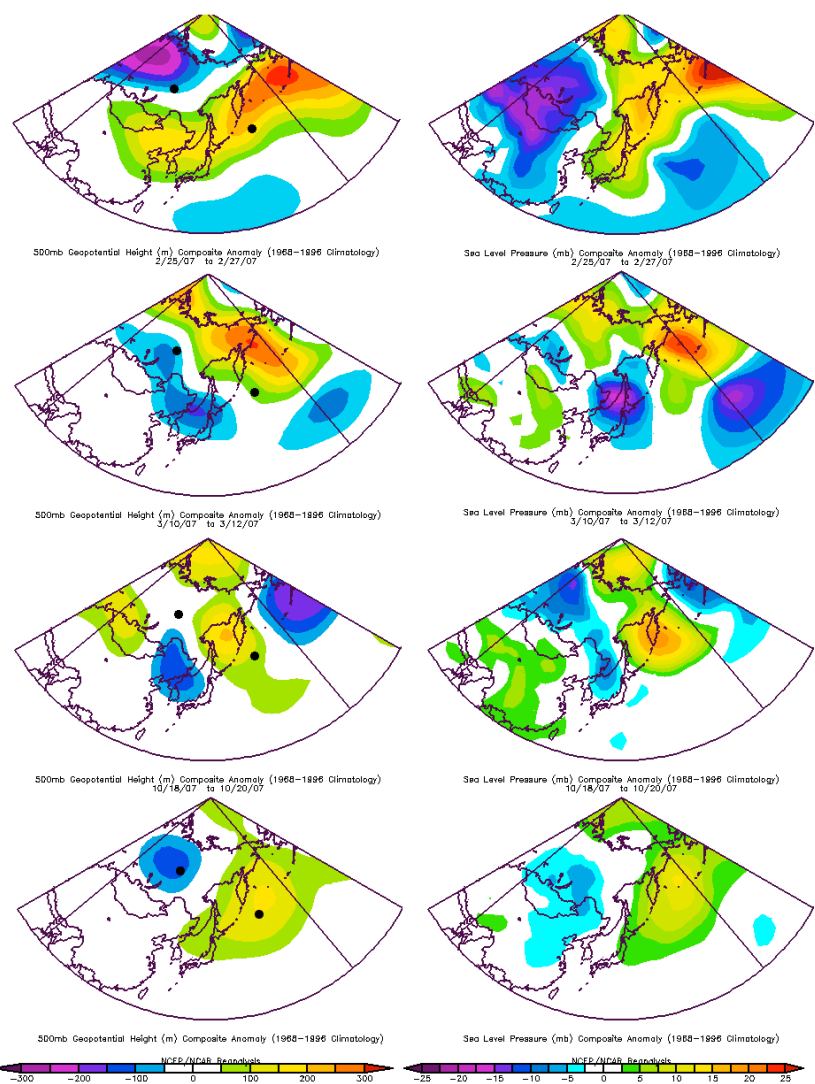

Fig. 12. $500 \mathrm{hPa}$ Geopotential height anomaly pattern (left panels) and Sea Level Pressure anomaly (right panels) for the 3-day initial stage of export to the Arctic of the three case studies discussed here: 25-27 February, 10-12 March , and 18-20 October. Bottom panels: composite of all eleven episodes observed by CALIOP in 2007-2009. Two circles indicate the location of the two poles used to define the AME index. Images provided by the NOAA/ESRL Physical Sciences Division, Boulder Colorado from their Web site at http://www.esrl.noaa.gov/psd/.

out of 11 episodes, with near zero or positive values in the remaining 6 episodes. The PNA index is negative during 4 out of 11 events.

Three-year time series of daily WP and PNA index values are contrasted to the variability in Asian transport to the Arctic, which we define as the model Asian anthropogenic sulfate AOD at $70^{\circ} \mathrm{N}$ averaged between $120^{\circ} \mathrm{E}$ and $180^{\circ} \mathrm{E}$ (Fig. 13, top and middle panel). The WP index displays little to no correlation with Asian Sulfate AOD, with correlation coefficients below 0.2 (Table 4). The PNA index shows more success at capturing the variability in the Asian Sulfate AOD time series, especially in winter and summer. The negative correlation coefficients in Table 4 are consistent with strong blocking activity in the central North Pacific occurring during negative phases of PNA (Wallace and Gutzler, 1981).

We define a new empirical meteorological index by calculating the difference in $500 \mathrm{hPa}$ geopotential height 

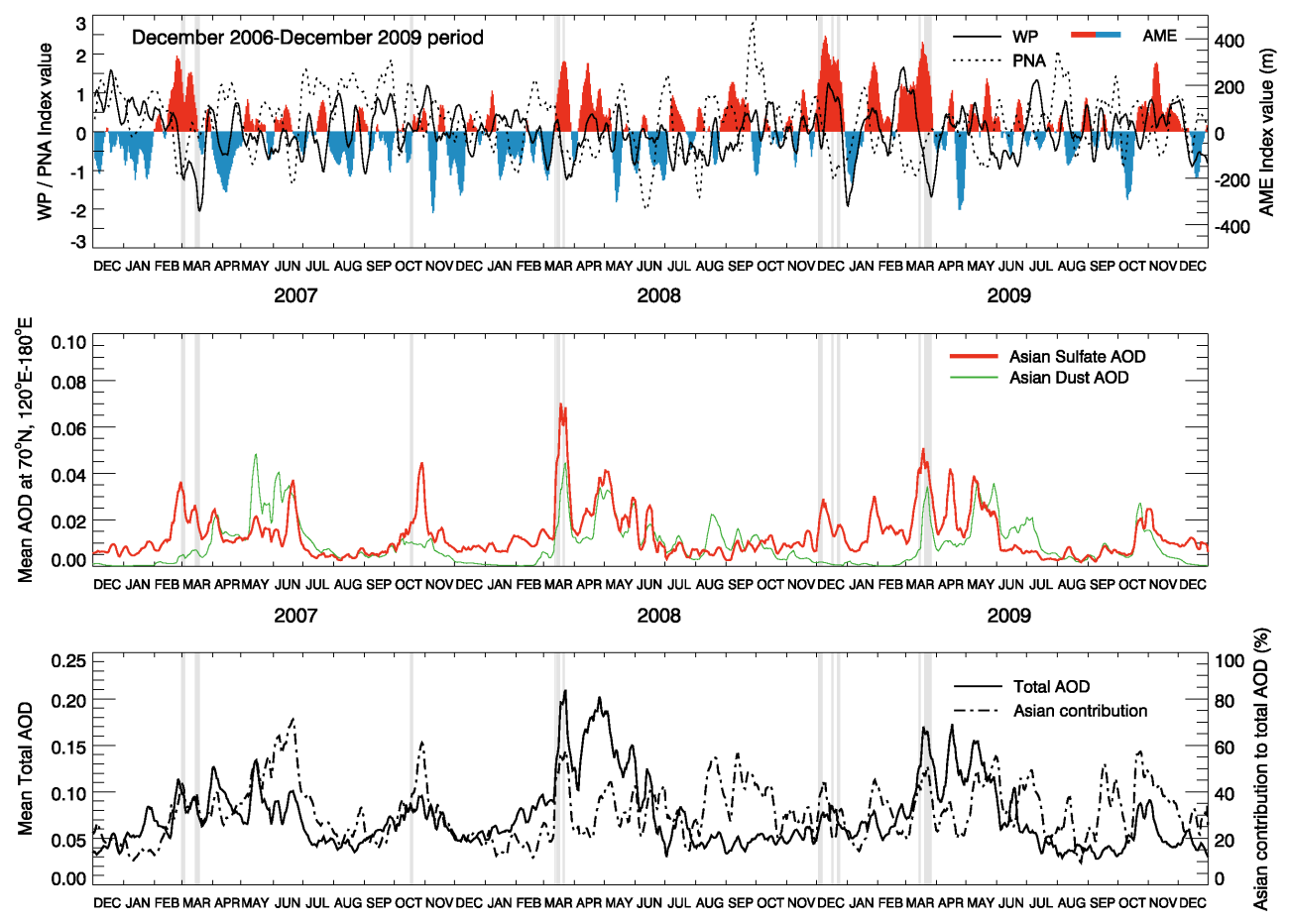

Fig. 13. Time series of meteorological indices and Asian AOD for December 2006-December 2009. Top panel: WP, PNA, and AME (red = positive, blue $=$ negative) indices. The WP index is based on Wallace and Gutzler (1981) and the PNA index is obtained from http: //www.cpc.noaa.gov/products/precip/CWlink/daily_ao_index/history/history.shtml. See text for the definition of the AME index. A two-day lag is applied to all indices. Middle panel: Asian Sulfate and Asian Dust AOD calculated by GEOS-Chem at $70^{\circ} \mathrm{N}$ averaged between $120^{\circ} \mathrm{E}$ and $180^{\circ} \mathrm{E}$. Bottom panel: Total AOD at $70^{\circ} \mathrm{N}$ averaged between $120^{\circ} \mathrm{E}$ and $180^{\circ} \mathrm{E}$ and percentage contributed by Asia. All timeseries are smoothed with a 7-day running mean. The vertical grey bars show the 11 instances when CALIOP intercepted Asian plumes over the Arctic.

Table 4. Correlations of WP, PNA and AME index defined in the text with the Asian anthropogenic sulfate AOD at $70^{\circ} \mathrm{N}$ averaged between $120^{\circ} \mathrm{E}$ and $180^{\circ} \mathrm{E}$.

\begin{tabular}{lrrl}
\hline & \multicolumn{3}{c}{ Index $^{\mathrm{a}}$} \\
\cline { 2 - 4 } Seasons & WP & PNA & AME \\
\hline DJF & -0.01 & -0.45 & $\mathbf{0 . 7 6}^{\mathrm{b}}$ \\
MAM & -0.08 & -0.35 & $\mathbf{0 . 6 3}$ \\
JJA & -0.19 & -0.47 & 0.07 \\
SON & 0.17 & -0.17 & 0.26 \\
Entire timeseries & -0.13 & $-\mathbf{0 . 3 8}$ & $\mathbf{0 . 4 7}$ \\
(Dec 2006-Dec 2009) & & & \\
\hline
\end{tabular}

a Timeseries are smoothed with a 7-day running mean. A 2-day lag is applied to all indices. ${ }^{\mathrm{b}}$ Values in bold are significant at $95 \%$ confidence level.

anomalies between two points $\left(160^{\circ} \mathrm{E}, 47.5^{\circ} \mathrm{N}\right.$ and $120^{\circ} \mathrm{E}$, $\left.60^{\circ} \mathrm{N}\right)$, near the east-west centers of action in the anomaly composites of Fig. 12. We call this index the Asian Meridional Export (AME) index. All 11 events are associated with positive values of AME (Table 3, Fig. 13). During winter and spring the AME index is strongly correlated with the anthro- pogenic Asian time series $(r=0.76$ and $r=0.63$, Table 4). The correlation of AME with the Asian anthropogenic AOD peaks at a lag of 2 days, which corresponds to the transport time from the mid-latitudes to $70^{\circ} \mathrm{N}$. The strength and persistence of meridional transport, as measured by AME, captures 40-60\% of the variance in the modeled Asian anthropogenic $\mathrm{AOD}$ at $70^{\circ} \mathrm{N}$ in winter/spring. The AME index thus appears to be a good predictor of export of Asian pollution to the Arctic. During summer and autumn, the correlation between AME and Asian Sulfate AOD disappears as both time series display much less variability (Fig. 13). This reflects a more zonal configuration of geopotential height with a diminished frequency of blocking patterns in the Northern Pacific in summer/early autumn (Lejenas and Økland, 1983), leading to reduced outflow of pollution from East Asia to the Arctic.

Finally, we use the GEOS-Chem model to examine Asian export to the Arctic in a broader context. We find that 6 major export episodes occur each year, with half these events taking place between March and June, in phase with positive values of the AME index (Fig. 13). Sometimes, events occur in winter (February 2007, December 2008, January 2009) and autumn (October 2007 and 2009). Transport during spring events takes place at $4-8 \mathrm{~km}$ altitude, while it is restricted to 
altitudes below $2 \mathrm{~km}$ during winter. Winter and early spring episodes are dominated by sulfate, with dust making a significant contribution in late spring to early summer, consistent with the seasonality of Asian dust storms (Shao and Dong, 2006). In some export events, the contribution from Asian dust can exceed that of Asian sulfate. Over the Siberian sector, Asian sulfate and dust account for $33 \%$ of the total AOD in GEOS-Chem, on average (Fig. 13, bottom panel). During major transport episodes, the Asian contribution increases to $50-70 \%$, with a contribution increasing with altitude: 55$75 \%$ at $2-5 \mathrm{~km}$ altitude and $60-80 \%$ at $5-10 \mathrm{~km}$.

\section{Conclusions}

We used observations from the space borne lidar onboard CALIPSO satellite together with the GEOS-Chem chemical transport model, and lagrangian backtrajectories to follow the evolution of three aerosol export events from East Asia to the Arctic in 2007. Two of the export episodes took place in early spring, the time when Arctic Haze is at its climatological peak, whereas the third occurred in autumn. Haze layers were detected at altitudes of $2-8 \mathrm{~km}$, exhibited a poleward tilt following potential temperature surfaces. Individual layers had a mean thickness of $\sim 1.5 \mathrm{~km}$. We found good agreement between model simulations and observations as to the geographical location, thickness, and altitude of the haze layers.

The mean observed optical depth of aerosol layers was 0.04 (cases 1 and 3) with depolarization ratio consistently around 0.03; in the second springtime case the AOD was not available due to the misclassification of aerosols as clouds. In this case, we found a mean integrated attenuated backscatter of $1.21 \times 10^{-3} \mathrm{sr}^{-1}$, and higher values of the depolarization ratio, in the $0.05-0.07$ range. Values of color ratio are found to be mostly between 0.2 and 0.3 in all cases.

The dominant source region for the aerosol layers is NE China. In $5-10 \%$ of the individual aerosols layers, backtrajectories indicate an origin in the Gobi desert. The export pathway followed by the mixture of pollution and dust was similar in all three case studies. Pollutants first accumulated in the shallow boundary layer and were then exported to the free troposphere by a developing cyclone or a waning cyclone approaching from the west. The polluted airmass then ascended rapidly ahead of the cold front, accompanied by significant precipitation in these early stages of transport. This was followed by rapid meridional transport to the Arctic mediated by either a blocking high in the western Pacific (spring export events) or a pronounced ridge (autumn export event). Once the ascent was complete, potential temperature slowly but steadily decreased at a rate of $\sim 1.5^{\circ} \mathrm{C} \mathrm{day}^{-1}$. Subsidence accompanied this radiative cooling, although it took place less gradually. No plume was observed to reach the surface.

In the export episode that took place in March, the CALIOP layer classification algorithm misclassifies a large number of aerosol layers as clouds. The misclassification occurs because the presence of dust poleward of $70^{\circ} \mathrm{N}$ is interpreted as ice crystals by the algorithm. The misclassification is more pronounced for daytime compared to nighttime retrievals.

We examined the relationship between the Western Pacific and Pacific North American indices and the frequency of occurrence of major aerosol export episodes from East Asia. While the WP index shows no correlation with export episodes, the PNA index displays a negative correlation, consistent with strong blocking activity occurring during negative phases of the PNA.

We defined an empirical index, the Arctic Meridional Export (AME), based on a composite of the anomaly pattern of $500 \mathrm{hPa}$ heights of 11 major export events in 20072009. AME correlates well with enhanced export of Asian pollution to the Arctic during winter $(r=0.76)$ and spring $(r=0.63)$, and is thus more successful than the PNA and WP indices at capturing the variability of these export events.

Simulations with the GEOS-Chem model showed that, on average, 6 major export events from Asia to the Arctic occur each year. These events maximize during March-June, with a secondary maximum in October-November. The AOD contribution of Asian pollution and dust aerosols increases to $50-70 \%$ during these events, compared to a mean background contribution of $33 \%$.

CALIOP measurements provide a potential method of resolving the discrepancies among CTMs in that it can provide constraints on the vertical location and amount of aerosols transported to the Arctic. The model calculated plume AOD and backscatter fall within the uncertainties range of the CALIOP measurements $( \pm 40 \%)$. The sharper boundaries of the aerosol layers observed by CALIOP are partly a result of the altitude dependent sensitivity of the instrument. The CALIOP detection accuracy however is sensitive to the illumination conditions which affect the signal-to-noise ratio. Our case studies took place under favorable conditions for retrievals, since the transport was rapid (and consequently the plumes underwent little dilution), and occurred mainly at nighttime. As the sun rises over the Arctic it becomes more problematic to detect faint pollution aerosol plumes transported over long distances and to track them over time. This aspect has to be carefully considered if one aims at constructing a satellite-based long-term climatology of the vertical distribution of haze layers over the Arctic.

\section{Supplementary material related to this article is available online at: http://www.atmos-chem-phys.net/11/2225/2011/ acp-11-2225-2011-supplement.pdf.}


Acknowledgements. This work was supported by funding from the National Aeronautic and Space Administration under award NNX08Q07G. We also acknowledge the NASA Langley Research Center Atmospheric Science Data Center for the CALIPSO data. T. L. Anderson acknowledges additional support from the National Science Foundation (grant \# ATM-0601177).

Edited by: B. N. Duncan

\section{References}

Alexander, B., Savarino, J., Lee, C. C. W., Park, R. J., Jacob, D. J., Thiemens, M. H., Li, Q. B., and Yantosca, R. M.: Sulfate formation in sea-salt aerosols: Constraints from oxygen isotopes, J. Geophys. Res., 110, D10307, doi:10.1029/2004JD005659, 2005.

Barriopedro, D., Garcia-Herrera, R., Lupo, A., and Hernandez, E.: A climatology of Northern Hemisphere Blocking, J. Climate, 19, 1042-1063, 2006.

Bey, I., Jacob, D. J., Yantosca, R. M., Logan, J. A., Field, B. D., Fiore, A. M., Li, Q., Liu, H. Y., Mickley, L. J., and Schultz, M. G.: Global modeling of tropospheric chemistry with assimilated meteorology: Model description and evaluation, J. Geophys. Res., 106(D19), 23073-23095, 2001.

Bourdages, L., Duck, T. J., Lesins, G., Drummond, J. R., and Eloranta, E. W.: Physical properties of High Arctic tropospheric particles during winter, Atmos. Chem. Phys., 9, 6881-6897, doi:10.5194/acp-9-6881-2009, 2009.

Carlson, T. N.: Speculations on the movement of polluted air to the Arctic, Atmos. Environ., 15(8), 1473-1477, 1981.

Chen, S.-J., Kuo, Y.-H., Zhang, P.-Z., and Bai, Q.-F.: Synoptic Climatology of Cyclogenesis over East Asia, 1958-1987, Am. Meteor. Soc., 119, 1407-1418, 1991.

Curry, J.: On the formation of continental polar air, Am. Meteor. Soc., 40, 2278-2292, 1983.

Draxler, R. R. and Hess, G. D.: Description of the HYSPLIT_4 Modeling System, NOAA Technical Memorandum ERL ARL224, revised January 2004.

Fairlie, T. D., Jacob, D. J., and Park, R. J.: The impact of transpacific transport of mineral dust in the United States, Atmos. Environ., 41, 1251-1266, 2007.

Ishii, S., Shibata, T., Sakai, T., Kido, M., Hara, K., Osada, K., Iwasaka, Y., Nagai, T., Fujimoto, T., Itabe, T., Mizutani, K., and Uchino, O.: The source, size and chemical composition of the winter Arctic tropospheric aerosol layer observed by lidar at Eureka, Canada, J. Meteorol. Soc. Jpn., 79(1), 61-78, 2001.

Iversen, T. and Joranger, E.: Arctic air pollution and large-scale atmospheric flows, Atmos. Environ., 19(12), 2099-2108, 1985.

Kalnay, E., Kanamitsu, M., Kistler, R., Collins, W., Deaven, D., Gandin, L., Iredell, M., Saha, S., White, G., Woollen, J., Zhu, Y., Chelliah, M., Ebisuzaki, W., Higgins, W., Janowiak, J., Mo, K. C., Ropelewski, C., Wang, J., Leetmaa, A., Reynolds, R., Jenne, R., and Joseph, D.: The NCEP/NCAR Reanalysis 40-year Project, Bull. Am. Meteor. Soc., 77, 437-471, 1996.

Klonecki, A., Hess, P., Emmons, L., Smith, L., Orlando, J., and Blake, D.: Seasonal changes in the transport of pollutants into the Arctic troposphere-model study, J. Geophys. Res., 108(D4), 8367, doi:10.1029/2002JD002199, 2003.

Koch, D. and Hansen, J.: Distant origins of Arctic black carbon: A Goddard Institute for Space Studies ModelE experiment, J.
Geophys. Res., 110, D04204, doi:10.1029/2004JD005296, 2005.

Lejenas, H. and Økland, H.: Characteristics of northern hemisphere blocking as determined from a long time series of observational data, Tellus, 35A, 350-362, 1983.

Liao, H, Seinfeld, J., Wu, S., and Mickley, L.: Biogenic Secondary Organic Aerosol over the United States: Comparison of Climatological Simulations with Observations, J. Geophys. Res, 112, D06201, doi:10.1029/2006JD007813, 2007.

Liu, D., Wang, Z., Liu, Z., Winker, D., and Trepte, C.: A height resolved global view of dust aerosols from the first year CALIPSO lidar measurements, J. Geophys. Res., 113, D16214, doi:10.1029/2007JD009776, 2008.

Liu, H., Jacob, D. J., Bey, I., and Yantosca, R. M.: Constraints from ${ }^{210} \mathrm{~Pb}$ and ${ }^{7} \mathrm{Be}$ on wet deposition and transport in a global threedimensional chemical tracer model driven by assimilated meteorological fields, J. Geophys. Res., 106, 12109-12128, 2001.

Liu, Z., Vaughan, M. A., Winker, D. M., Hostetler, C. A., Poole, L. R., Hlavka, D., Hart, W., and McGill, M.: Use of probability distribution functions for discriminating between cloud and aerosol in lidar backscatter data, J. Geophys. Res., 109, D15202, doi:10.1029/2004JD004732, 2004.

Liu, Z., Vaughan, M. A., Winker, D. M., Kittaka, C., Kuehn, R. E., Getzewich, B. J., Trepte, C. R., and Hostetler, C. A.: The CALIPSO Lidar Cloud and Aerosol Discrimination: Version 2 Algorithm and Initial Assessment of Performance, J. Atmos. Ocean. Tech., 26, 1198-1213, doi:10.1175/2009JTECHA1229.1, 2009.

Liu, Z., Kuehn, R., Vaughan, M., Winker, D., Omar, A., Powell, K., Trepte, C., Hu, Y., and Hostetler, C.: The CALIPSO Cloud And Aerosol Discrimination: Version 3 Algorithm and Test Results, 25th International Laser Radar Conference (ILRC), St. Petersburg, Russia, 2010.

Martin, R. V., Jacob, D. J., Yantosca, R. M., Chin, M., and Ginoux, P.: Global and regional decreases in tropospheric oxidants from photochemical effects of aerosols, J. Geophys. Res., 108, 4097, doi:10.1029/2002JD002622, 2003.

Mitchell, M.: Visual range in the polar regions with particular reference to the Alaskan Arctic, J. Atmos. Terr. Phys., Special Supplement, 195-211, 1956.

Olivier, J. G. J. and Berdowski, J. J. M.: Global emissions sources and sinks, in: The Climate System, edited by: Berdowski, J., Guicherit, R., and Heij, B. J., A. A. Balkema Publishers/Swets $\&$ Zeitlinger Publishers, Lisse, The Netherlands, ISBN 90-5809255-0, 33-78, 2001.

Park, R. J., Jacob, D. J., Chin, M., and Martin, R. V.: Sources of carbonaceous aerosols over the United States and implications for natural visibility, J. Geophys. Res., 108(D12), 4355, doi:10.1029/2002JD003190, 2003.

Park, R. J., Jacob, D. J., Field, B. D., Yantosca, R. M., and Chin, M.: Natural and transboundary pollution influences on sulfate-nitrate-ammonium aerosols in the United States: implications for policy, J. Geophys. Res., 109, D15204, doi:10.1029/2003JD004473, 2004.

Park, R. J., Jacob, D. J., Palmer, P. I., Clarke, A. D., Weber, R. J., Zondlo, M. A., Eisele, F. L., Bandy, A. R., Thornton, D. C., Sachse, G. W., and Bond, T. C.: Export efficiency of black carbon aerosol in continental outflow: Global implications, J. Geophys. Res., 110, D11205, doi:10.1029/2004JD005432, 2005.

Quinn, P. K., Miller, T. L., Bates, T. S., Ogren, J. A., Andrews, E., 
and Shaw, G. E.: A three year record of simultaneously measured aerosol chemical and optical properties at Barrow, Alaska, J. Geophys. Res., 107(D11), 4130, doi:10.1029/2001JD001248, 2002.

Rastigejev, Y., Park, R., Brenner, M. P., and Jacob, D. J.: Resolving intercontinental pollution plumes in global models of atmospheric transport, J. Geophys. Res., 115, D02302, doi:10.1029/2009JD012568, 2010.

Shao, Y. and Dong, C. H.: A review on East Asian dust storm climate, modeling and monitoring, Glob. Planet. Change, 52, 1-22, 2006.

Shaw, G. E.: The Arctic Haze phenomenon, Bull. Am. Meteorol. Soc., 76, 2403-2413, 1995.

Shindell, D. T., Chin, M., Dentener, F., Doherty, R. M., Faluvegi, G., Fiore, A. M., Hess, P., Koch, D. M., MacKenzie, I. A., Sanderson, M. G., Schultz, M. G., Schulz, M., Stevenson, D. S., Teich, H., Textor, C., Wild, O., Bergmann, D. J., Bey, I., Bian, H., Cuvelier, C., Duncan, B. N., Folberth, G., Horowitz, L. W., Jonson, J., Kaminski, J. W., Marmer, E., Park, R., Pringle, K. J., Schroeder, S., Szopa, S., Takemura, T., Zeng, G., Keating, T. J., and Zuber, A.: A multi-model assessment of pollution transport to the Arctic, Atmos. Chem. Phys., 8, 5353-5372, doi:10.5194/acp-8-5353-2008, 2008.

Stohl, A.: Characteristics of atmospheric transport into the Arctic troposphere, J. Geophys. Res., 111, D11306, doi:10.1029/2005JD006888, 2006.

van der Werf, G. R., Randerson, J. T., Giglio, L., Collatz, G. J., Kasibhatla, P. S., and Arellano Jr., A. F.: Interannual variability in global biomass burning emissions from 1997 to 2004, Atmos. Chem. Phys., 6, 3423-3441, doi:10.5194/acp-6-3423-2006, 2006.
Vaughan, M., Young, S., Winker, D., Powell, K., Omar, A., Liu, Z., Hu, Y., and Hostetler, C.: Fully automated analysis of space-based lidar data: an overview of the CALIPSO retrieval algorithms and data products, Proc. SPIE, 5575, 16-30, doi:10.1117/12.572024, 2004.

Wallace, J. M. and Gutzler, D. S.: Teleconnections in the Geopotential Height Field during the Northern Hemisphere Winter, Mon. Weather Rev., 109, 784-812, 1981.

Wang, Y., Jacob D. J., and Logan J. A.: Global simulation of tropospheric O3-NOx-hydrocarbon chemistry, 1. Model formulation, J. Geophys. Res., 103(D9), 10713-10726, 1998.

Winker D. M., Hunt, W., and Hostetler, C.: Status and performance of the CALIOP lidar, Proc. SPIE Int. Soc. Opt. Eng., 5575, 8-15, 2004.

Winker, D. M., Vaughan, M. A., Omar, A., Hu, Y., and Powell, J. A.: Overview of the CALIPSO Mission and CALIOP Data Processing Algorithms, J. Atmos. Ocean. Tech., 26, 2310-2323, doi:10.1175/2009JTECHA1281.1, 2009.

Young, S. A. and Vaughan, M. A.: The retrieval of profiles of particulate extinction from Cloud Aerosol Lidar Infrared Pathfinder Satellite Observations (CALIPSO) data: Algorithm description, J. Atmos. Ocean. Tech., 26, 1105-1119, doi:10.1175/2008JTECHA1221.1, 2009.

Zender, C. S., Bian, H., and Newman, D.: The mineral dust entrainment and deposition (DEAD) model: description and 1990s dust climatology, J. Geophys. Res, 108(D14), 4416, doi:10.1029/2002JD002775, 2003.

Zhang, Q., Streets, D. G., Carmichael, G. R., He, K. B., Huo, H., Kannari, A., Klimont, Z., Park, I. S., Reddy, S., Fu, J. S., Chen, D., Duan, L., Lei, Y., Wang, L. T., and Yao, Z. L.: Asian emissions in 2006 for the NASA INTEX-B mission, Atmos. Chem. Phys., 9, 5131-5153, doi:10.5194/acp-9-5131-2009, 2009. 